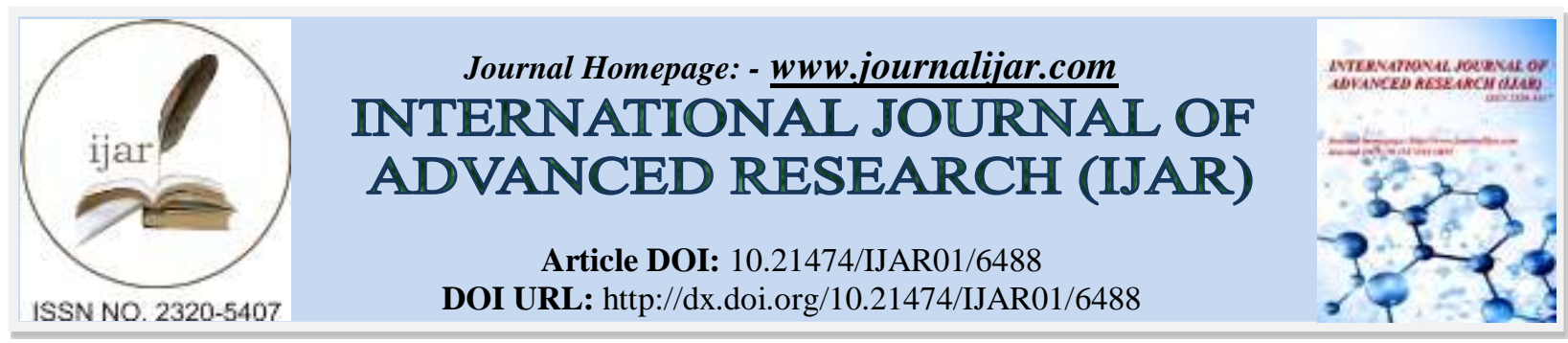

RESEARCH ARTICLE

\title{
IMPACT OF SMALL GROUP INTERACTIVE EDUCATION, ON CHILDHOOD ASTHMA LEVEL OF CONTROL.
}

\section{Dr. Ahmed Helmy Ahmed Ewais, Dr. Sherif Mostafa Kamal Reda, Dr. Shahenaz Mahmoud Hussein, Dr. Hussein Mohammed El-Assal and Dr. Ahmed Yousef EL-Sawah. Professor of Pediatrics \& Neonatology, Faculty of Medicine, Al-Azhar University.}

\section{Manuscript Info}

Manuscript History

Received: 09 December 2017

Final Accepted: 11 January 2018

Published: February 2018

\section{Abstract}

Copy Right, IJAR, 2018,. All rights reserved.

\section{Acknowledgment:-}

First and for most, thanks are all to "Allah", the Most Beneficial, Merciful, the Most Gracious and without his help this work couldn't be completed.

I would like to express my sincere gratitude and respect to my Professor Dr. Sherif Mostafa Kamal Reda, Professor of Pediatrics, Faculty of Medicine, Al-Azhar University, for his mostly and valuable advice and kind supervision throughout the whole work.

I would like to express my sincere gratitude to Professor Dr. Shahenaz Mahmoud Hussein, Professor of Pediatrics, Faculty of Medicine, Al-Azhar University, for her kind supervision, wide guidance and continuous support

I would like to express my sincere gratitude to Professor Dr. Hussein Mohammed El-Assal, Professor of Pediatrics, Faculty of Medicine, Al-Azhar University, for his kind supervision, wide guidance and continuous support.

I would like to express my sincere gratitude to Professor Dr. Ahmed Yousef EL-Sawah, Professor of Pediatrics, Faculty of Medicine, Al-Azhar University, for his kind supervision, wide guidance and continuous support.

\section{Introduction:-}

$M$ anagement of asthma often focuses on "crisis intervention, meaning that the disease is addressed only when a problem occurs. Shifting emphasis to a preventive health model, which includes guided self-management, has been shown to reduce costs related to hospital admissions and visits to emergency departments (1).

Patient education is becoming an essential area of service provision, with our increasing population of people with chronic diseases and conditions requiring long term management in the community. Much of the morbidity from asthma is believed to be due to factors such as denial of having a chronic condition (2).

Thus, patient education has become a key component of asthma management for asthma patients at all age groups (3). 


\section{AIM OF THE WORK:-}

To compare between the impacts of small group interactive education (using the asthma education program) versus the usual visit of the asthma follow up clinic, on childhood asthma outcome regarding the level of control as well as the net changes of some laboratory investigations

\section{HiSTORICAL BACKGROUND:-}

The word 'asthma' is derived from the Greek aazein, meaning "sharp breath." The word first-appears in Homer's Iliad; Hippocrates was the first to use it in reference to the medical condition, in $450 \mathrm{BC}$. Hippocrates thought that the spasms associated with asthma were more likely to occur in tailors, anglers, and metalworkers (4).

Six centuries later, Galen wrote much about asthma, noting that it was caused by partial or complete bronchial obstruction. In 1190 AD, Moses Maimonides, an influential medieval rabbi, philosopher, and physician, wrote a treatise on asthma, describing its prevention, diagnosis, and treatment (5).

\section{Definitions:}

Asthma is a chronic inflammatory disorder of the airways in which many cells and cellular elements play a role. The chronic inflammation is associated with airway hyperresponsiveness that leads to recurrent episodes of wheezing, breathlessness, chest tightness, and coughing, particularly at night or in the early morning. These episodes are usually associated with widespread, but variable, airflow obstruction within the lung that is often reversible either spontaneously or with treatment.

Since its pathogenesis is not clear, this definition is descriptive and inclusive of different phenotypes that are being increasingly recognized both on clinical grounds, including responsiveness to treatment, and on the basis of genetic and causative pathological features. There is now good evidence that the clinical manifestations of asthma (symptoms, sleep disturbances, limitations of daily activity, impairment of lung function and use of rescue medications) can, in a large proportion of patients, be controlled with appropriate treatment. When asthma is controlled, there should be no more than occasional recurrence of symptoms and severe exacerbations should be rare (6).

Patients And Methods:-

The present study is an intervention study aimed to assess and improve treatment adherence of asthmatic children through increasing knowledge, changing attitude and teaching skills of those asthmatic patients. This was done through health education programs which supposed to improve the understanding of the disease, management skills, and treatment compliance as well as the importance of follow up.

The study was conducted in the Pediatric allergy and pulmonology clinics, Al-Azhar University Hospitals; (Al Hussein and Sayed Galal hospitals). The study period was from 1st of June 2013 to end of November, 2013 including follow up visits of the children.

Study Design:

Cross sectional study.

Patients:

90 asthmatic patients (all degrees of persistent asthma) enrolled in the study, their ages ranged from 6 months to 12 years; they were chosen among patients attending the Pediatric allergy and pulmonology clinics, Al-Azhar University Hospitals after fitting the inclusion and exclusion criteria.

Inclusion Criteria:-

(1) Age between 6 months and 12 years.

(2) Have a confirmed diagnosis of bronchial asthma in the medical record by history, examination and investigations.

(3) Using rescue and controller medications as inhalers.

(4) Categorized as poor or partial controlled asthmatic patients.

Exclusion Criteria:-

(1) Age less than 6 months and more than12 years.

(2) Refuse using rescue or controller medications as inhalers. 
(3) Those with significant associated co-morbidity (e.g. heart, renal disease).

(4) Categorized as good controlled asthmatic patients.

The enrolled patients were randomly clustered selected and randomly divided into two major groups (A \& B).

Plan of the study:

90 asthmatic Patients enrolled in the study, and divided into 2 major groups:

(1) Group A (nonintervention group) which included 30 patients, receive the usual care at the follow up clinic, according to the asthma clinic protocol of our department:

1. History and clinical examination.

2. Pulmonary index.

3. PEFR (whenever their age is permissible).

4. Radiological and lab investigation when needed.

(2) Group B (intervention group) which included 60 patients, divided into 3 equal subgroups (B1, B2, B3). They attached to the Asthma Education Program (AEP) sessions, each session involved at least 10 children alone or in accompany with their parents / caregivers according to their ages.

(a) Group B1which included 20 patients their ages more than 6 months and less than 5 years, the sessions targeted the parents/caregivers only.

(b) Group B2 which included 20 patients their ages is 5 years and up to 8 years, the sessions targeted the children and their caregivers.

(c) Group B3 which included 20 patients their ages between 9 years and 12 years, the sessions targeted the children only.

All the patients were assessed at the baseline for the level of control, according to the following parameters; times of using rescue inhaler, number of days absent from school or work absence of the parents, number of days of restricted activity, number of disturbed nights, number of visits to the emergency department and frequency of hospitalizations. All the patients were investigated for esinophilic count and pulmonary function tests if their ages are permissible to do the test before starting of the study.

Clinical Examination:

All selected children were subjected to:

1. General examination.

2. Local chest examination especially auscultation before and after bronchodilator inhalation therapy.

3. Accurate assessment of severity of the asthma attack.

4. Pulmonary function tests or PEFR were done if the child was cooperative and his age was permissible.

Repeated clinical examination, during the follow up were done to evaluate the impact of the program.

Education Program for Asthma:

Asthma Education Program (AEP) consisting of 3 education sessions, 2 weeks apart, at the allergy and pulmonology unit. Each session dealt with a lesson and required 30 minutes. After the end of the education sessions, patients instructed to come for follow up visits at week 2, 4, 8 and 12. After follow up period both groups reevaluated for level of control by the same parameters mentioned before.

The educational program was targeted the parents/caregivers and child with core content adapted for age level as appropriate. Materials used are pictures with puzzle education (fig. 5, 6, 7) videos showing a demo for using inhalers, interaction between the physician and parents or children. Results was tabulated and statistically analyzed.

The curriculum for children is part of the Asthma Awareness: Curriculum for the Elementary Classroom which was developed by the National Heart, Lung, and Blood Institute (NHBLI). There are three lessons for grades K-3, each requiring approximately 30 minutes per session. Instruction for grades 4-6 is divided into three lessons, each about 30 minutes in length.

The curriculum for parents is three lessons to educate parents/caregivers of children with asthma about the proper treatment and management of the childhood asthma. The lessons were created using the Environmental Protection Agency and Centers of Disease Control booklet entitled Help Your Child Gain Control Over Asthma. 
There is also some supplementary information included from two National Heart, Lung and Blood Institute brochures: So You Have Asthma brochure, and Managing Asthma brochure: A Guide for Schools, as well as Medline Plus (Asthma -Control Drugs, How to use a nebulizer and Asthma Airways graphic which can be found on the What is Asthma?) which is an online service of the U.S. Library of Medicine at the National Institutes of Health.

The information presented in these lessons correlate with the information in the children's curriculum so that the parents and children will be learning the same information.

It is our hope that this will foster a thoughtful conversation between children and their parents and help them gain control over asthma.I

All of the lessons are designed to:

- Develop a basic understanding of asthma and help correct misinformation.

- Explanation of asthma triggers and what to do to control them.

- Highlight that children can lead active lives with asthma.

- Provide resources to share with parents and other family members.

Sessions for children included:

Session 1:- What Is Asthma?

Session 2:- What Makes Asthma Worse?

Session 3:- : What Can Children with Asthma do to stay healthy?

Sessions for parents included:

Session 1:- Learn about Asthma.

Session 2:- Asthma Action Plans and Medications.

Session 3:- Asthma triggers and how to control them

Results:-

Table 1:- Descriptive data for the study population.

\begin{tabular}{|l|l|l|}
\hline sex & N & $\%$ \\
\hline Female & & \\
\hline Male & 29 & 32.2 \\
\hline Education level & 61 & 67.8 \\
\hline illiterate & & \\
\hline educated & 54 & 60.0 \\
\hline Age & 36 & 40.0 \\
\hline 6 m-5 years & & \\
\hline$>5-8$ years & 30 & 33.3 \\
\hline$>8-12$ years & 30 & 33.3 \\
\hline Family history of asthma & 30 & 33.3 \\
\hline Negative family history of asthma & & \\
\hline Positive family history of asthma & 38 & 42.2 \\
\hline Family history of smoking & 52 & 57.8 \\
\hline Negative family history of smoking & & 54.4 \\
\hline Positive family history of smoking & 49 & 45.6 \\
\hline
\end{tabular}


Table 2:- comparative data of the study population according to the gender

\begin{tabular}{|c|c|c|c|c|c|c|c|}
\hline \multirow{2}{*}{\multicolumn{2}{|c|}{ Sex }} & \multicolumn{2}{|c|}{ Non intervention } & \multicolumn{2}{|c|}{ Intervention } & \multicolumn{2}{|c|}{ Total } \\
\hline & & $\mathbf{N}$ & $\%$ & $\mathbf{N}$ & $\%$ & $\mathbf{N}$ & $\%$ \\
\hline \multicolumn{2}{|l|}{ Female } & 8 & 26.7 & 21 & 35.0 & 29 & 32.2 \\
\hline \multicolumn{2}{|l|}{ Male } & 22 & 73.3 & 39 & 65.0 & 61 & 67.8 \\
\hline \multicolumn{2}{|l|}{ Total } & 30 & 100.0 & 60 & 100.0 & 90 & 100.0 \\
\hline \multirow[t]{2}{*}{ Chi-square } & $X^{2}$ & \multicolumn{6}{|c|}{0.636} \\
\hline & P-value & \multicolumn{6}{|c|}{0.425} \\
\hline
\end{tabular}

This table shows that $67.8 \%$ of the studied cases were males and $32.2 \%$ were females.

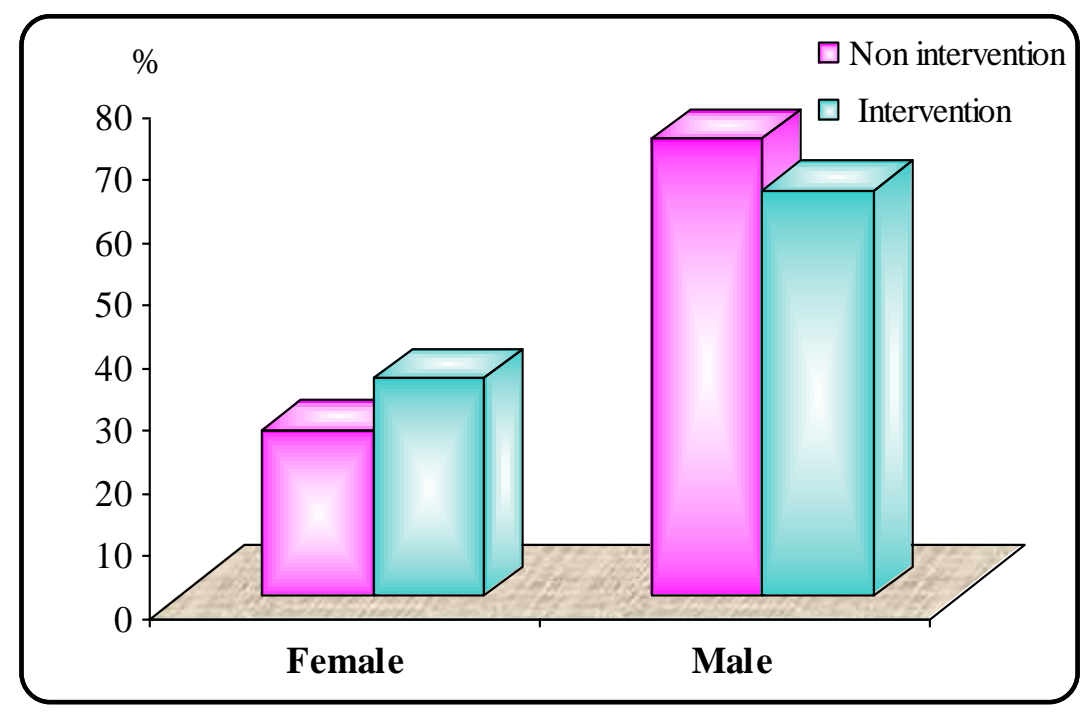

Figure 1:- Descriptive data for the study population according to gender.

Table 3:- comparative data of the study population according to education.

\begin{tabular}{|c|c|c|c|c|c|c|c|}
\hline \multirow{2}{*}{\multicolumn{2}{|c|}{ Education level }} & \multicolumn{2}{|c|}{ Non intervention } & \multicolumn{2}{|c|}{ Intervention } & \multicolumn{2}{|c|}{ Total } \\
\hline & & $\mathbf{N}$ & $\%$ & $\mathbf{N}$ & $\%$ & $\mathbf{N}$ & $\%$ \\
\hline \multicolumn{2}{|l|}{ Illiterate } & 12 & 40.0 & 42 & 70.0 & 54 & 60.0 \\
\hline \multicolumn{2}{|l|}{ Educated } & 18 & 60.0 & 18 & 30.0 & 36 & 40.0 \\
\hline \multicolumn{2}{|l|}{ Total } & 30 & 100.0 & 60 & 100.0 & 90 & 100.0 \\
\hline \multirow[t]{2}{*}{ Chi-square } & $\mathbf{X}^{2}$ & \multicolumn{6}{|c|}{7.500} \\
\hline & P-value & \multicolumn{6}{|c|}{$0.006^{*}$} \\
\hline
\end{tabular}

Non sig. $>0.05$ Sig. $<0.05^{*}$ High sig. $<0.001$

This table shows that $40 \%$ of the studied population were educated and $60 \%$ was illiterate. 


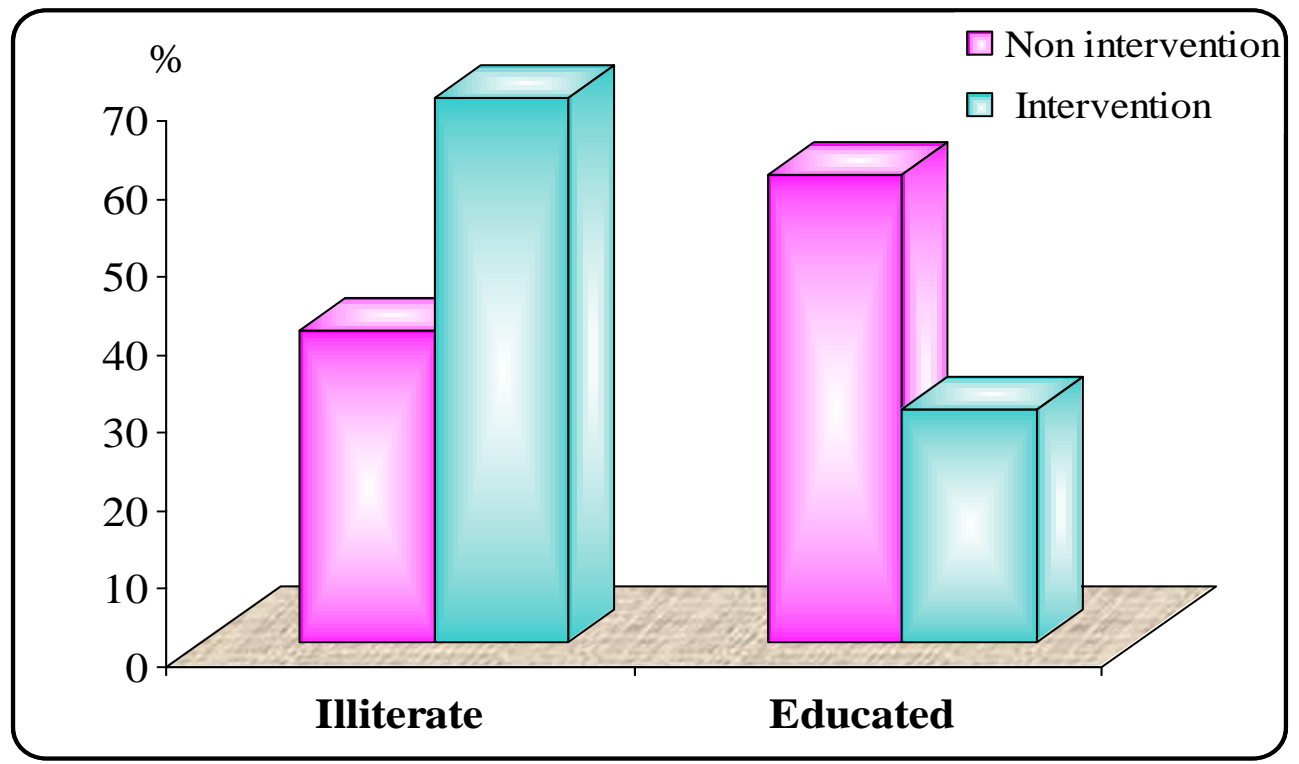

Figure 2:- Descriptive data for the study population according to education.

Table 4:- comparative data of the study population according to family history of asthma.

\begin{tabular}{|c|c|c|c|c|c|c|c|}
\hline \multirow{2}{*}{\multicolumn{2}{|c|}{ Family history of asthma }} & \multicolumn{2}{|c|}{ Non intervention } & \multicolumn{2}{|c|}{ Intervention } & \multicolumn{2}{|c|}{ Total } \\
\hline & & $\mathbf{N}$ & $\%$ & $\mathbf{N}$ & $\%$ & $\mathbf{N}$ & $\%$ \\
\hline \multicolumn{2}{|c|}{ Negative family history asthma (-ve F.H. asthma) } & 14 & 46.7 & 24 & 40.0 & 38 & 42.2 \\
\hline \multicolumn{2}{|c|}{ Positive family history of asthma (+ve F.H. asthma) } & 16 & 53.3 & 36 & 60.0 & 52 & 57.8 \\
\hline \multicolumn{2}{|c|}{ Total } & 30 & 100.0 & 60 & 100.0 & 90 & 100.0 \\
\hline \multirow[t]{2}{*}{ Chi-square } & $\mathbf{X}^{2}$ & \multicolumn{6}{|c|}{0.364} \\
\hline & P-value & \multicolumn{6}{|c|}{0.546} \\
\hline
\end{tabular}

Non sig. $>0.05$ Sig. $<0.05 *$ High sig. $<0.001$

This table shows that $42.2 \%$ of the studied patients has no a family history of asthma and $57.8 \%$ has a family history of asthma.

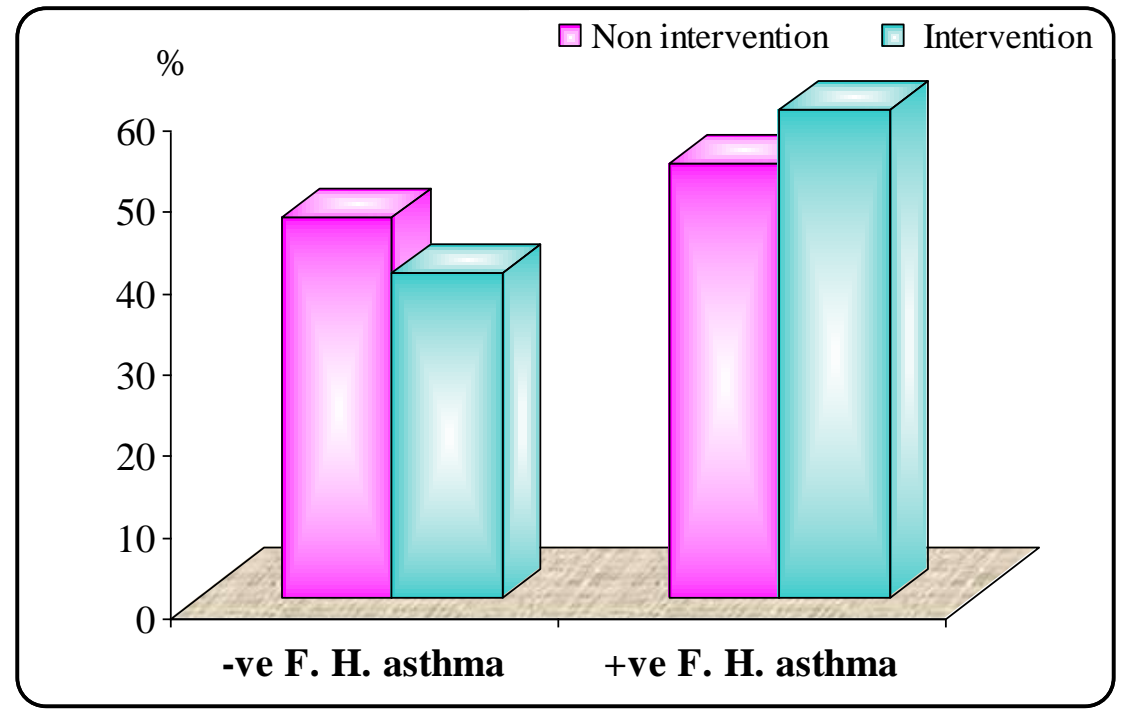

Figure 3:- Descriptive data for the study population according to family history of asthma 
Table 5:- comparative data of the study population according to family history of smoking

\begin{tabular}{|c|c|c|c|c|c|c|c|}
\hline \multirow{3}{*}{\multicolumn{2}{|c|}{ Family history of smoking (F.H Smoking) }} & \multicolumn{6}{|c|}{ Intervent } \\
\hline & & \multicolumn{2}{|c|}{ Non intervention } & \multicolumn{2}{|c|}{ Intervention } & \multicolumn{2}{|c|}{ Total } \\
\hline & & $\mathbf{N}$ & $\%$ & $\mathbf{N}$ & $\%$ & $\mathbf{N}$ & $\%$ \\
\hline \multicolumn{2}{|c|}{ Negative family history of smoking. } & 15 & 50.0 & 34 & 56.7 & 49 & 54.4 \\
\hline \multicolumn{2}{|c|}{ Positive family history of smoking. } & 15 & 50.0 & 26 & 43.3 & 41 & 45.6 \\
\hline \multicolumn{2}{|c|}{ Total } & 30 & 100.0 & 60 & 100.0 & 90 & 100.0 \\
\hline \multirow[t]{2}{*}{ Chi-square } & $\mathbf{X}^{2}$ & \multicolumn{6}{|c|}{0.358} \\
\hline & P-value & \multicolumn{6}{|c|}{0.549} \\
\hline
\end{tabular}

Non sig. >0.05 Sig. <0.05* High sig. $<0.001$

This table shows that $45.6 \%$ of the studied patients have a family history of smoking and $54.4 \%$ doesn't have a family history of smoking.

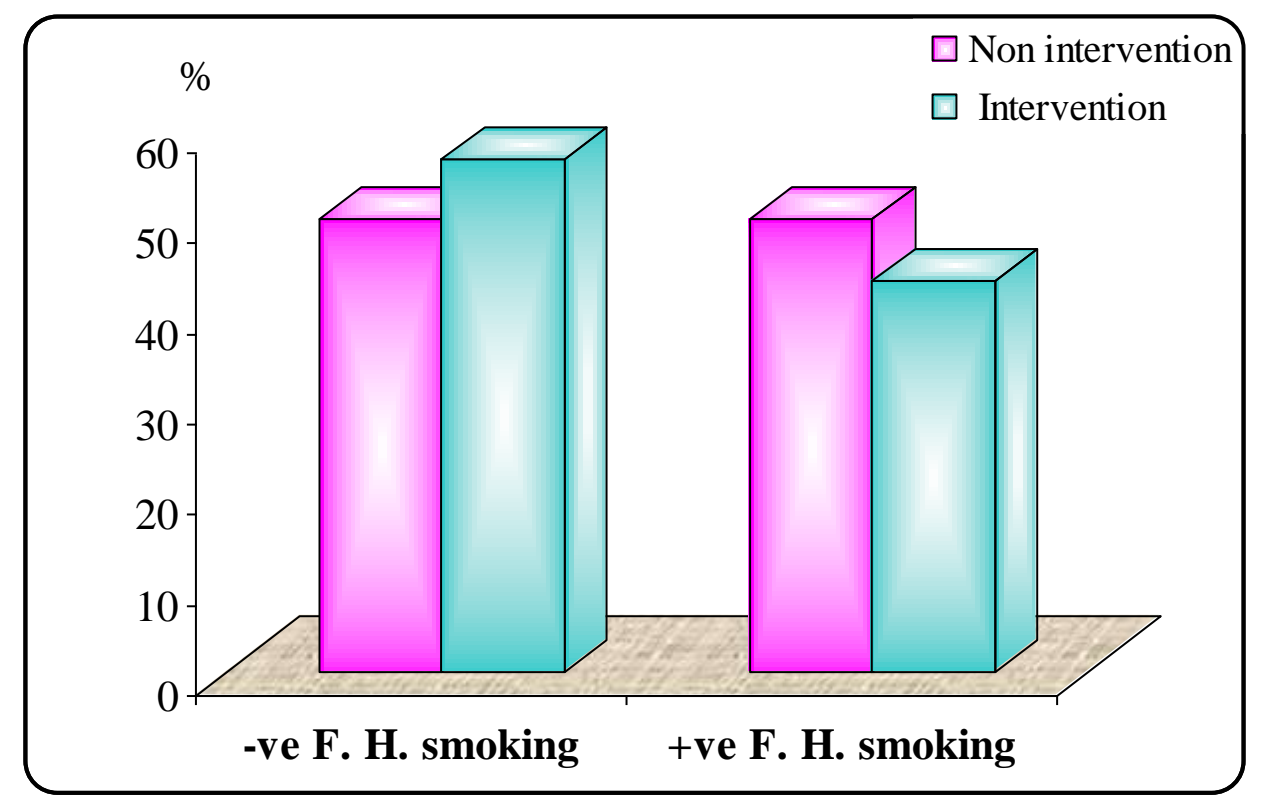

Figure 4:- Descriptive data for the study population according to family history of smoking.

Table 6:- Comparison between intervention and non intervention group as number of days of restricted activities per week due to asthma during each follow up visit.

\begin{tabular}{|c|c|c|c|c|c|c|c|c|}
\hline & \multicolumn{3}{|c|}{$\begin{array}{l}\text { Non } \\
\text { intervention }\end{array}$} & \multicolumn{3}{|c|}{ Intervention } & \multicolumn{2}{|c|}{ T-test } \\
\hline & $\begin{array}{l}\text { Mea } \\
\text { n }\end{array}$ & \pm & SD & $\begin{array}{l}\text { Mea } \\
\text { n }\end{array}$ & \pm & SD & $\mathbf{t}$ & $\begin{array}{l}\text { P- } \\
\text { value }\end{array}$ \\
\hline $\begin{array}{l}\text { Number of days of restricted activities per week before } \\
\text { follow up }\end{array}$ & 2.23 & \pm & $\begin{array}{l}0.8 \\
6\end{array}$ & 1.97 & \pm & $\begin{array}{l}0.8 \\
0\end{array}$ & $\begin{array}{l}1.45 \\
3\end{array}$ & 0.150 \\
\hline $\begin{array}{l}\text { Number of days of restricted activities per week at } 2 \text { weeks } \\
\text { follow up visits }\end{array}$ & 1.98 & \pm & $\begin{array}{l}0.6 \\
6\end{array}$ & 1.60 & \pm & $\begin{array}{l}0.4 \\
3\end{array}$ & $\begin{array}{l}2.32 \\
9\end{array}$ & $\begin{array}{l}0.022 \\
*\end{array}$ \\
\hline $\begin{array}{l}\text { Number of days of restricted activities per week at } 4 \text { weeks } \\
\text { follow up visits }\end{array}$ & 1.87 & \pm & $\begin{array}{l}0.5 \\
1\end{array}$ & 1.00 & \pm & $\begin{array}{l}0.3 \\
2\end{array}$ & $\begin{array}{l}2.40 \\
4\end{array}$ & $\begin{array}{l}0.018 \\
*\end{array}$ \\
\hline $\begin{array}{l}\text { Number of days of restricted activities per week at } 8 \text { weeks } \\
\text { follow up visits }\end{array}$ & 1.63 & \pm & $\begin{array}{l}0.6 \\
6 \\
\end{array}$ & 0.37 & \pm & $\begin{array}{l}0.1 \\
9\end{array}$ & $\begin{array}{l}.03 \\
1 \\
\end{array}$ & $\begin{array}{l}0.000 \\
*\end{array}$ \\
\hline $\begin{array}{l}\text { Number of days of restricted activities per week at } 12 \text { weeks } \\
\text { follow up visits }\end{array}$ & 1.33 & \pm & $\begin{array}{l}0.5 \\
8\end{array}$ & 0.28 & \pm & $\begin{array}{l}0.1 \\
5\end{array}$ & $\begin{array}{l}3.44 \\
4\end{array}$ & $\begin{array}{l}0.001 \\
*\end{array}$ \\
\hline
\end{tabular}

Non sig. $>0.05$ Sig. $<0.05^{*}$ High sig. $<0.001^{*}$ 
This table shows that reduction of days occur in both groups starting from the first follow up visit but reduction occur more in the interventional group. It was also noticed that the comparison was statistically significant starting from the first follow up visit then become highly significant at the end of the period of the follow up.

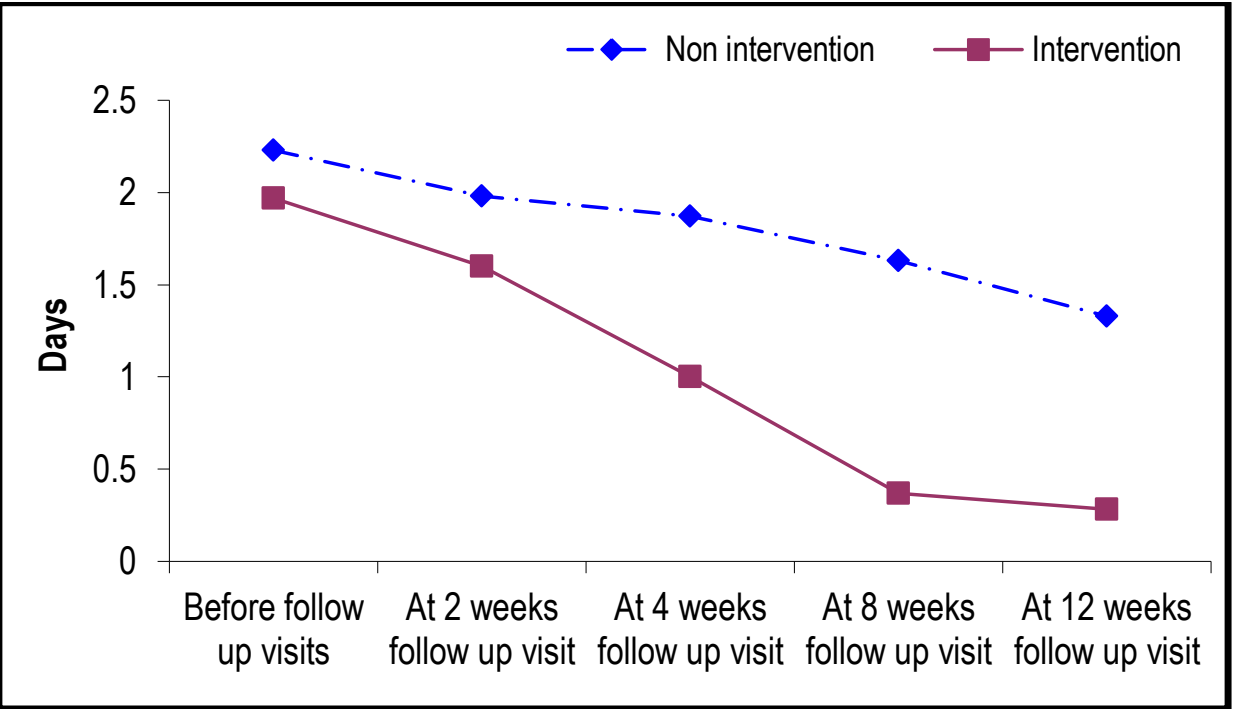

Figure 5:- Occurrence of number of days of restricted activities per week during the study period.

Table 7:- Comparison between the difference in days of restricted activities per week due to asthma before the follow up and each follow up visit in both interventional and non-interventional group.

\begin{tabular}{|c|c|c|}
\hline & $\begin{array}{l}\text { Non } \\
\text { intervention }\end{array}$ & $\begin{array}{l}\text { Interventi } \\
\text { on }\end{array}$ \\
\hline \multicolumn{3}{|l|}{ Paired t-test } \\
\hline $\begin{array}{l}\text { Difference in number of days of restricted activities before follow up and at } 2 \\
\text { weeks follow up visit. }\end{array}$ & 0.447 & $0.029 *$ \\
\hline $\begin{array}{l}\text { Difference in number of days of restricted activities before follow up and at } 4 \\
\text { weeks follow up visit. }\end{array}$ & 0.195 & $0.000 *$ \\
\hline $\begin{array}{l}\text { Difference in number of days of restricted activities before follow up and at } 8 \\
\text { weeks follow up visit. }\end{array}$ & $0.030 *$ & $0.000 *$ \\
\hline $\begin{array}{l}\text { Difference in number of days of restricted activities before follow up and at } 12 \\
\text { weeks follow up visit. }\end{array}$ & $0.000 *$ & $0.000 *$ \\
\hline
\end{tabular}

Non sig. $>0.05$ Sig. $<0.05 *$ High sig. $<0.001 *$

By using paired t-test, this table clarified that the comparison was statistically significant starting from the first follow up visit in the interventional group whereas it wasn't statistically significant until the third follow up visit in the non-interventional group.

Table 8:- Comparison between intervention and non intervention group as regard absence from school due to asthma during each follow up visit

\begin{tabular}{|c|c|c|c|c|c|c|c|c|}
\hline & \multicolumn{3}{|c|}{$\begin{array}{l}\text { Non } \\
\text { intervention }\end{array}$} & \multicolumn{3}{|c|}{ Intervention } & \multicolumn{2}{|c|}{ T-test } \\
\hline & $\begin{array}{l}\text { Mea } \\
\mathbf{n}\end{array}$ & \pm & SD & $\begin{array}{l}\text { Mea } \\
\mathbf{n}\end{array}$ & \pm & SD & $\mathbf{t}$ & $\begin{array}{l}\text { P- } \\
\text { value }\end{array}$ \\
\hline $\begin{array}{l}\text { Number of days of absence from school before follow up } \\
\text { visits }\end{array}$ & 2.20 & \pm & 0.66 & 2.13 & \pm & $\begin{array}{l}0.6 \\
8\end{array}$ & $\begin{array}{l}0.70 \\
3\end{array}$ & 0.458 \\
\hline $\begin{array}{l}\text { Number of days of absence from school at } 2 \text { weeks follow } \\
\text { up visit }\end{array}$ & 1.97 & \pm & 0.53 & 0.98 & \pm & $\begin{array}{l}0.4 \\
1\end{array}$ & $\begin{array}{l}1.93 \\
2\end{array}$ & $0.007 *$ \\
\hline $\begin{array}{l}\text { Number of days of absence from school at } 4 \text { weeks follow } \\
\text { up visit }\end{array}$ & 1.90 & \pm & 0.53 & 0.50 & \pm & $\begin{array}{l}0.2 \\
4\end{array}$ & $\begin{array}{l}3.38 \\
4\end{array}$ & $0.001 *$ \\
\hline Number of days of absence from school at 8 weeks follow & 1.57 & \pm & 0.63 & 0.43 & \pm & 0.2 & 3.30 & $0.001 *$ \\
\hline
\end{tabular}




\begin{tabular}{|l|l|l|l|l|l|l|l|l|}
\hline up visit & & & & & & 2 & 8 & \\
\hline $\begin{array}{l}\text { Number of days of absence from school at 12 weeks } \\
\text { follow up visit }\end{array}$ & 0.93 & \pm & 0.51 & 0.25 & \pm & $\begin{array}{l}0.1 \\
0\end{array}$ & $\begin{array}{l}2.74 \\
8\end{array}$ & $0.000^{*}$ \\
\hline
\end{tabular}

Non sig. $>0.05$ Sig. $<0.05^{*}$ High sig. $<0.001 *$

This table shows reduction occurs in both groups but more in interventional group. It was noticed that the comparison was statistically significant starting from the first follow up visit then become highly significant at the end of the period of follow up.

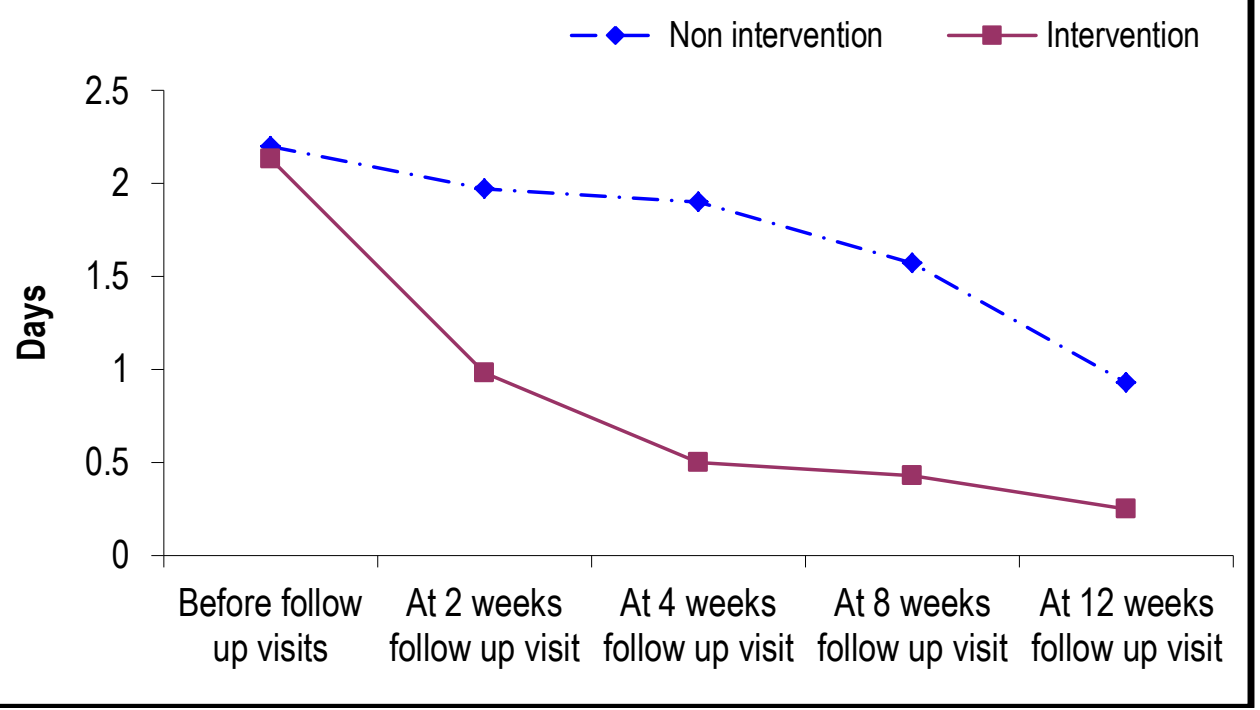

Figure 6:- Occurrence of number of days of absence from school per week due to asthma during the study period.

Table 9:- Comparison between the difference in number of days of absence from school per week due to asthma before the follow up and each follow up visit after sessions in both interventional and non interventional group.

\begin{tabular}{|c|c|c|}
\hline & $\begin{array}{l}\text { Non } \\
\text { interventio } \\
\text { n }\end{array}$ & $\begin{array}{l}\text { Interven } \\
\text { tion }\end{array}$ \\
\hline \multicolumn{3}{|l|}{ Paired t-test } \\
\hline $\begin{array}{l}\text { Difference in number of days of absence from school per week due to asthma before } \\
\text { follow up and at } 2 \text { weeks follow up visit. }\end{array}$ & 0.079 & $0.000^{*}$ \\
\hline $\begin{array}{l}\text { Difference in number of days of absence from school per week due to asthma before } \\
\text { follow up and at } 4 \text { weeks follow up visit }\end{array}$ & 0.175 & $0.000 *$ \\
\hline $\begin{array}{l}\text { Difference in number of days of absence from school per week due to asthma before } \\
\text { follow up and at } 8 \text { weeks follow up visit }\end{array}$ & $0.005^{*}$ & $0.000^{*}$ \\
\hline $\begin{array}{l}\text { Difference in number of days of absence from school per week due to asthma before } \\
\text { follow up and at } 12 \text { weeks follow up visit }\end{array}$ & $0.000 *$ & $0.000^{*}$ \\
\hline
\end{tabular}

Non sig. $>0.05$ Sig. $<0.05^{*}$ High sig. $<0.001^{*}$

By using paired t-test this table clarified that comparison between number of days of absence from school per week due to asthma before follow up and each follow up visit after sessions in both interventional and non interventional group and the comparison was statistically highly significant starting from the first follow up visit in the interventional group whereas wasn't statistically significant until the third follow up visit and only highly significant at the end of the follow up period in the non interventional group. 
Table 10:- Comparison between intervention and non intervention group as regard E.D. visits during each follow up visit

\begin{tabular}{|c|c|c|c|c|c|c|c|c|}
\hline & \multicolumn{3}{|c|}{$\begin{array}{l}\text { Non } \\
\text { intervention }\end{array}$} & \multicolumn{3}{|c|}{ Intervention } & \multicolumn{2}{|c|}{ T-test } \\
\hline & $\begin{array}{l}\text { Me } \\
\text { an }\end{array}$ & \pm & SD & $\begin{array}{l}\text { Me } \\
\text { an }\end{array}$ & \pm & SD & $\mathbf{t}$ & $\begin{array}{l}\text { P- } \\
\text { value }\end{array}$ \\
\hline $\begin{array}{l}\text { Number of times of E.D. visits per week due to asthma before } \\
\text { follow up visits. }\end{array}$ & 2.13 & \pm & $\begin{array}{l}0.7 \\
4\end{array}$ & 2.00 & \pm & $\begin{array}{l}0.6 \\
9 \\
\end{array}$ & $\begin{array}{l}1.68 \\
9\end{array}$ & 0.095 \\
\hline $\begin{array}{l}\text { Number of times of E.D. visits per week due to asthma at } 2 \\
\text { weeks follow up visit. }\end{array}$ & 1.93 & \pm & $\begin{array}{ll}0.6 \\
2\end{array}$ & 0.67 & \pm & $\begin{array}{ll}0.5 \\
1\end{array}$ & $\begin{array}{ll}10.2 \\
70\end{array}$ & $\begin{array}{l}0.000 \\
*\end{array}$ \\
\hline $\begin{array}{l}\text { Number of times of E.D. visits per week due to asthma at } 4 \\
\text { weeks follow up visit }\end{array}$ & 1.77 & \pm & $\begin{array}{ll}0.5 \\
3\end{array}$ & 0.53 & \pm & $\begin{array}{ll}0.5 \\
4\end{array}$ & $\begin{array}{l}8.53 \\
6 \\
\end{array}$ & $\begin{array}{l}0.000 \\
*\end{array}$ \\
\hline $\begin{array}{l}\text { Number of times of E.D. visits per week due to asthma at } 8 \\
\text { weeks follow up visit }\end{array}$ & 1.98 & \pm & $\begin{array}{l}0.4 \\
8\end{array}$ & 0.55 & \pm & $\begin{array}{l}0.5 \\
7\end{array}$ & $\begin{array}{l}9.43 \\
5\end{array}$ & $\begin{array}{l}0.000 \\
*\end{array}$ \\
\hline $\begin{array}{l}\text { Number of times of E.D. visits per week due to asthma at } 12 \\
\text { weeks follow up visit. }\end{array}$ & 1.53 & \pm & $\begin{array}{l}0.5 \\
0 \\
\end{array}$ & 0.42 & \pm & $\begin{array}{l}0.5 \\
0 \\
\end{array}$ & $\begin{array}{l}7.68 \\
7 \\
\end{array}$ & $\begin{array}{l}0.000 \\
*\end{array}$ \\
\hline
\end{tabular}

Non sig. $>0.05$ Sig. $<0.05 *$ High sig. $<0.001 *$

This table shows that reduction of number of times occurs in both groups but more in interventional group. It was also noticed that comparison was highly significant from the first follow up visit.

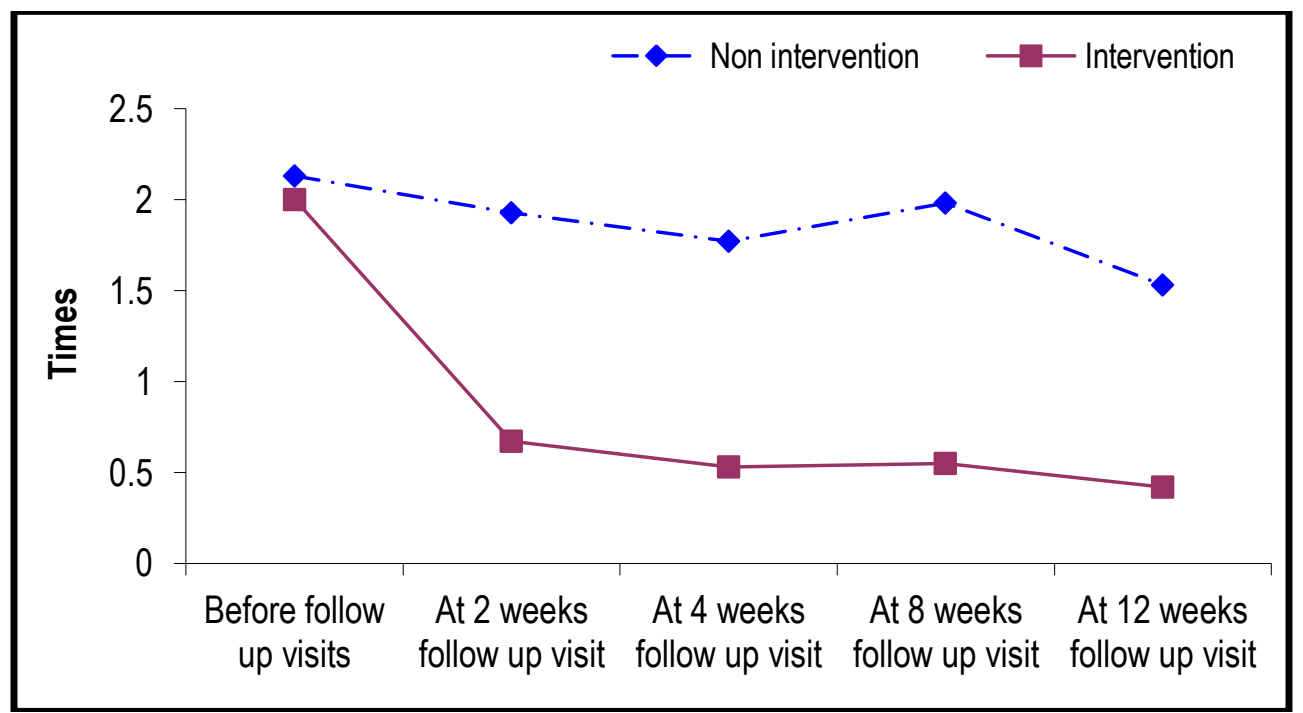

Figure 7:- Occurrence of number ED visits per week due to asthma during the study period.

Table 11:- Comparison between the difference in number of times of ED. visits per week due to asthma before follow up and each follow up visits in both interventional and non interventional group.

\begin{tabular}{|l|l|l|}
\hline \multicolumn{2}{|l|}{$\begin{array}{l}\text { Non } \\
\text { intervention }\end{array}$} & $\begin{array}{l}\text { Interven } \\
\text { tion }\end{array}$ \\
\hline Paired t-test & $0.000^{*}$ \\
\hline $\begin{array}{l}\text { Difference in number of times of E.D. visits per week due to asthma before follow up } \\
\text { and at } 2 \text { weeks follow up visit }\end{array}$ & 0.261 & $0.000^{*}$ \\
\hline $\begin{array}{l}\text { Difference in number of times of E.D. visits per week due to asthma before follow up } \\
\text { and at } 4 \text { weeks follow up visit }\end{array}$ & $0.045^{*}$ & $0.000^{*}$ \\
\hline $\begin{array}{l}\text { Difference in number of times of E.D. visits per week due to asthma before follow up } \\
\text { and at } 8 \text { weeks follow up visit }\end{array}$ & 0.398 & $0.000^{*}$ \\
\hline $\begin{array}{l}\text { Difference in number of times of E.D. visits per week due to asthma before follow up } \\
\text { and at } 2 \text { weeks follow up visit }\end{array}$ & $0.000^{*}$ & \\
\hline
\end{tabular}

Non sig. $>0.05$ Sig. $<0.05^{*}$ High sig. <0.001* 
By using paired t-test this table clarified that the comparison between number of times of E.D. visits per week due to asthma before follow up and each follow up visits in both interventional and non interventional group and the comparison was statistically highly significant from the first follow up visit but in the non interventional group whereas it was statistically highly significant only in the second follow up visit after session and highly significant at the end of the follow up period.

Table 12:- Comparison between intervention and non intervention group as regard times of rescue therapy per week during each follow up visit.

\begin{tabular}{|c|c|c|c|c|c|c|c|c|}
\hline & \multicolumn{3}{|c|}{$\begin{array}{l}\text { Non } \\
\text { intervention }\end{array}$} & \multicolumn{3}{|c|}{ Intervention } & \multicolumn{2}{|l|}{ T-test } \\
\hline & $\begin{array}{l}\text { Mea } \\
\text { n }\end{array}$ & \pm & SD & $\begin{array}{l}\text { Mea } \\
\text { n }\end{array}$ & \pm & SD & $\mathbf{t}$ & $\begin{array}{l}\text { P- } \\
\text { value }\end{array}$ \\
\hline $\begin{array}{l}\text { Number of times of use of rescue therapy /wk before } \\
\text { follow up visits }\end{array}$ & 5.53 & \pm & 1.20 & 6.20 & \pm & $\begin{array}{l}1.2 \\
2\end{array}$ & -4.462 & $0.016^{*}$ \\
\hline $\begin{array}{l}\text { Number of times of use of rescue therapy at } 2 \text { weeks follow } \\
\text { up visit }\end{array}$ & 5.23 & \pm & 1.09 & 1.02 & \pm & $\begin{array}{l}0.7 \\
5\end{array}$ & $\begin{array}{l}16.77 \\
2\end{array}$ & $0.000^{*}$ \\
\hline $\begin{array}{l}\text { Number of times of use of rescue therapy at } 4 \text { weeks follow } \\
\text { up visit }\end{array}$ & 4.97 & \pm & 1.10 & 0.92 & \pm & $\begin{array}{l}0.6 \\
7\end{array}$ & $\begin{array}{l}20.52 \\
1 \\
\end{array}$ & $0.000^{*}$ \\
\hline $\begin{array}{l}\text { Number of times of use of rescue therapy at } 8 \text { weeks follow } \\
\text { up visit }\end{array}$ & 4.67 & \pm & 1.06 & 0.93 & \pm & $\begin{array}{l}0.6 \\
9\end{array}$ & $\begin{array}{l}20.15 \\
3\end{array}$ & $0.000^{*}$ \\
\hline $\begin{array}{l}\text { Number of times of use of rescue therapy at } 12 \text { weeks } \\
\text { follow up visit }\end{array}$ & 4.50 & \pm & 0.94 & 0.58 & \pm & $\begin{array}{l}0.6 \\
5\end{array}$ & $\begin{array}{l}23.21 \\
8\end{array}$ & $0.000^{*}$ \\
\hline
\end{tabular}

Non sig. $>0.05$ Sig. $<0.05 *$ High sig. $<0.001$

This table shows that reduction in number of days occurs in both groups but it was more in the interventional group. It was also noticed that the comparison was highly significant from the first follow up visit.

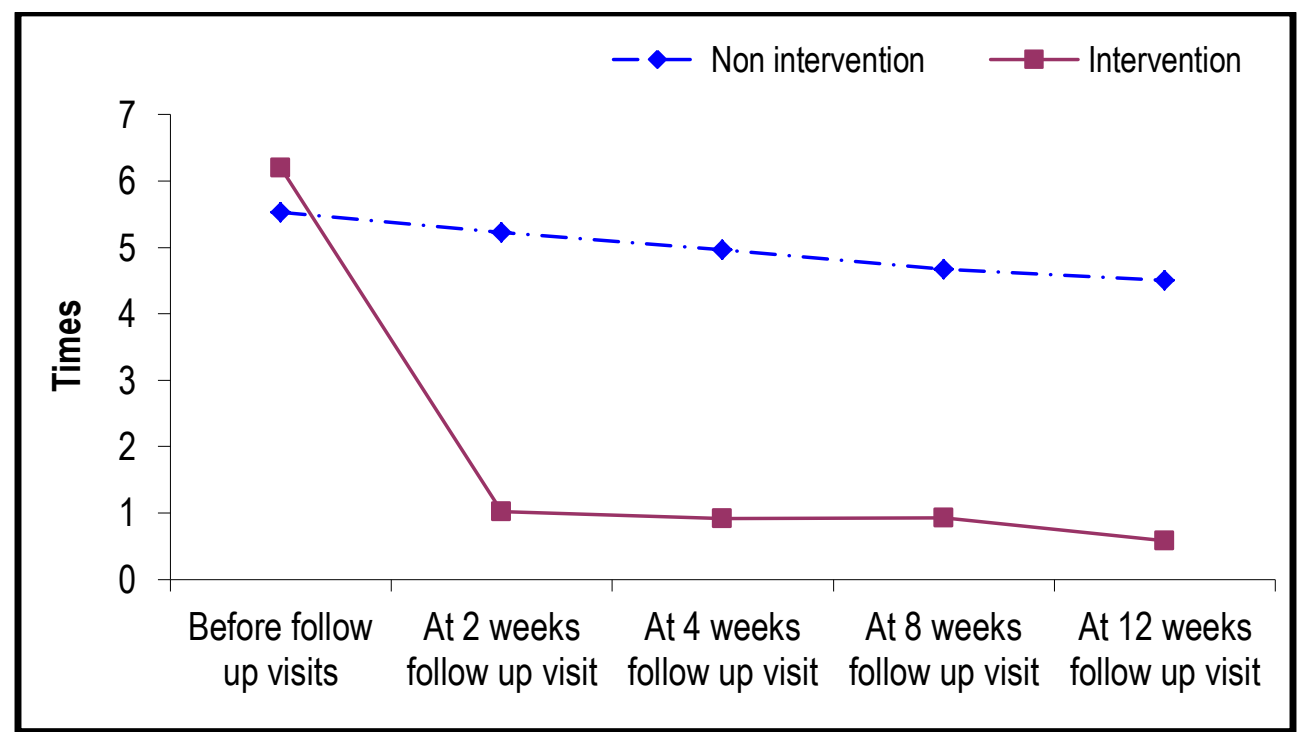

Figure 8:- Occurrence of number of use of rescue therapy per week during the study period.

Table 13:- Comparison between number of times of rescue therapy per week before follow up and each follow up visit after sessions in both interventional and non interventional group.

\begin{tabular}{|l|l|l|}
\hline & $\begin{array}{l}\text { Non } \\
\text { intervention }\end{array}$ & $\begin{array}{l}\text { Intervent } \\
\text { ion }\end{array}$ \\
\hline Paired t-test & 0.354 & $0.000^{*}$ \\
\hline $\begin{array}{l}\text { Difference in number of times of use of rescue therapy per week before follow up } \\
\text { and at } 2 \text { weeks follow up visit. }\end{array}$ & $0.000^{*}$ \\
\hline Difference in number of times of use of rescue therapy per week before follow up & 0.087 & 0.006 \\
\hline
\end{tabular}




\begin{tabular}{|l|l|l|}
\hline and at 4 weeks follow up visit & & \\
\hline $\begin{array}{l}\text { Difference in number of times of use of rescue therapy per week before follow up } \\
\text { and at } 8 \text { weeks follow up visit }\end{array}$ & $0.017^{*}$ & $0.000^{*}$ \\
\hline $\begin{array}{l}\text { Difference in number of times of use of rescue therapy per week before follow up } \\
\text { and at } 12 \text { weeks follow up visit }\end{array}$ & $0.003^{*}$ & $0.000^{*}$ \\
\hline
\end{tabular}

Non sig. $>0.05$ Sig. $<0.05^{*}$ High sig. $<0.001$

By using paired t-test this table clarified that comparison between number of times of rescue therapy per week before follow up and each follow up visit after sessions in both interventional and non interventional group and the comparison was highly significant from the first follow up visit in the interventional group whereas it was significant in the second follow up visit in the interventional group.

Table 14:- Comparison between intervention and non intervention group as regard nights disturbance per week during each follow up visit

\begin{tabular}{|c|c|c|c|c|c|c|c|c|}
\hline & \multicolumn{3}{|c|}{$\begin{array}{l}\text { Non } \\
\text { intervention }\end{array}$} & \multicolumn{3}{|c|}{ Intervention } & \multicolumn{2}{|c|}{ T-test } \\
\hline & $\begin{array}{l}\text { Mea } \\
\text { n }\end{array}$ & \pm & & $\begin{array}{l}\text { Mea } \\
\text { n }\end{array}$ & \pm & & $\mathbf{t}$ & $\begin{array}{l}\text { P- } \\
\text { value }\end{array}$ \\
\hline $\begin{array}{l}\text { Number of night disturbance per week due to asthma before } \\
\text { follow up visits }\end{array}$ & 1.83 & \pm & $\begin{array}{l}0.7 \\
0\end{array}$ & 2.13 & \pm & $\begin{array}{l}0.7 \\
5\end{array}$ & $\begin{array}{l}- \\
1.83 \\
4\end{array}$ & 0.070 \\
\hline $\begin{array}{l}\text { Number of night disturbance per week due to asthma at } 2 \\
\text { weeks follow up visits }\end{array}$ & 1.77 & \pm & $\begin{array}{l}0.4 \\
9\end{array}$ & 0.87 & \pm & $\begin{array}{l}0.4 \\
5\end{array}$ & $\begin{array}{l}8.32 \\
1\end{array}$ & $\begin{array}{l}0.001 \\
*\end{array}$ \\
\hline $\begin{array}{l}\text { Number of night disturbance per week due to asthma at } 4 \\
\text { weeks follow up visits }\end{array}$ & 1.60 & \pm & $\begin{array}{ll}0.5 \\
0\end{array}$ & 0.53 & \pm & $\begin{array}{l}0.3 \\
0\end{array}$ & $\begin{array}{ll}6.85 \\
5\end{array}$ & $\begin{array}{l}0.000 \\
*\end{array}$ \\
\hline $\begin{array}{l}\text { Number of night disturbance per week due to asthma at } \\
\text { 8weeks follow up visits }\end{array}$ & 1.45 & \pm & $\begin{array}{l}0.4 \\
7 \\
\end{array}$ & 0.40 & \pm & $\begin{array}{l}0.2 \\
3\end{array}$ & $\begin{array}{l}9.18 \\
9\end{array}$ & $\begin{array}{l}0.000 \\
*\end{array}$ \\
\hline $\begin{array}{l}\text { Number of night disturbance per week due to asthma at } 12 \\
\text { weeks follow up visits }\end{array}$ & 1.33 & \pm & $\begin{array}{l}0.5 \\
1\end{array}$ & 0.25 & \pm & $\begin{array}{l}0.1 \\
2\end{array}$ & $\begin{array}{l}9.98 \\
8\end{array}$ & $\begin{array}{l}0.000 \\
*\end{array}$ \\
\hline
\end{tabular}

Non sig. $>0.05$ Sig. $<0.05^{*}$ High sig. $<0.001$

This table shows that reduction of night disturbance occurs in both groups but occurs more in the interventional group and it was also noticed that the comparison was significant from the first follow up visit then become highly significant in the following follow up visit.

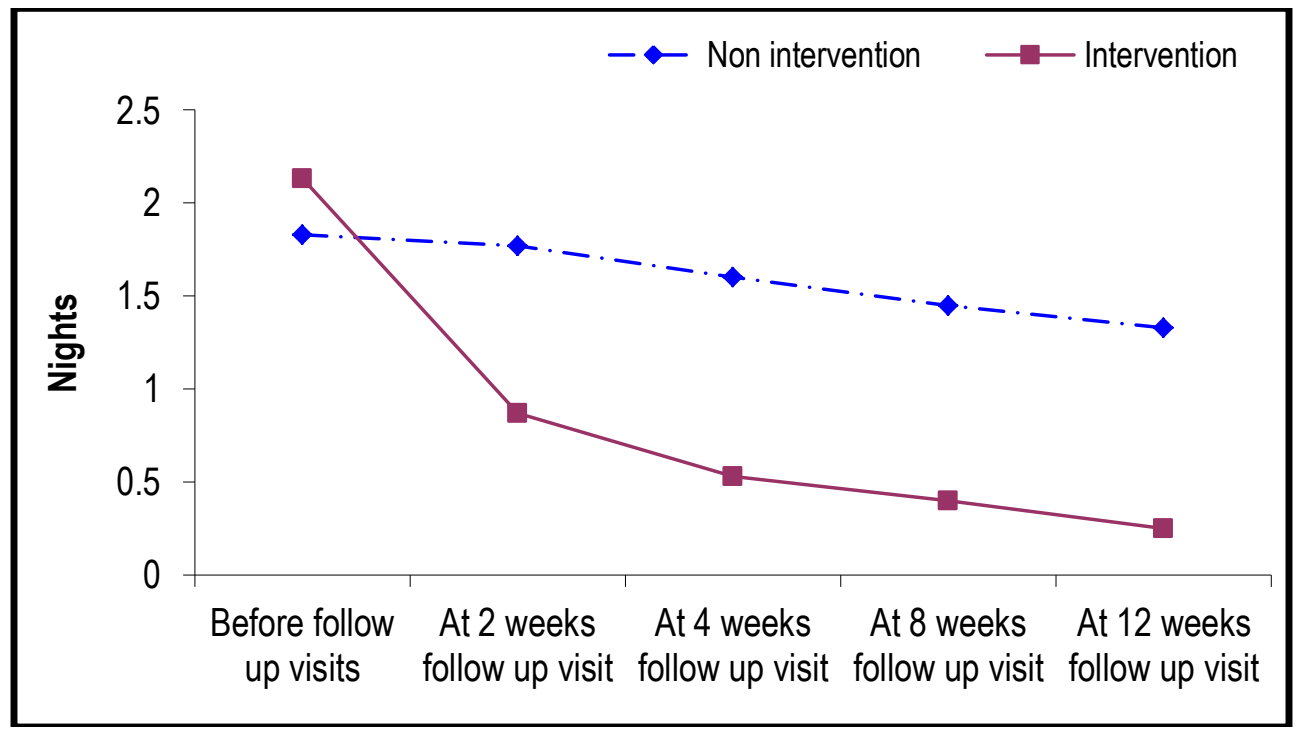

Figure 9:- Occurrence of number of night disturbance per week due to asthma during the study period. 
Table 15:- Comparison between the difference in number of night disturbance per week due to asthma before the follow up and each follow up visit in both interventional and non interventional group.

\begin{tabular}{|l|l|l|}
\hline & $\begin{array}{l}\text { Non } \\
\text { intervention }\end{array}$ & $\begin{array}{l}\text { Interven } \\
\text { tion }\end{array}$ \\
\hline \multicolumn{2}{|l|}{ Paired t-test } & $0.000^{*}$ \\
\hline $\begin{array}{l}\text { Difference in number of night disturbance per week due to asthma before follow up } \\
\text { and at } 2 \text { weeks follow up visit }\end{array}$ & 0.701 & $0.000^{*}$ \\
\hline $\begin{array}{l}\text { Difference in number of night disturbance per week due to asthma before follow up } \\
\text { and at } 4 \text { weeks follow up visit }\end{array}$ & 0.145 & $0.000^{*}$ \\
\hline $\begin{array}{l}\text { Difference in number of night disturbance per week due to asthma before follow up } \\
\text { and at 8weeks follow up visit }\end{array}$ & $0.017^{*}$ & $0.000^{*}$ \\
\hline $\begin{array}{l}\text { Difference in number of night disturbance per week due to asthma before follow up } \\
\text { and at } 12 \text { weeks follow up visit }\end{array}$ & $0.002^{*}$ & \\
\hline
\end{tabular}

Non sig. $>0.05$ Sig. $<0.05^{*}$ High sig. $<0.001$

By using paired t-test this table clarified that comparison between number of night disturbance per week due to asthma before follow up visit and each follow up visit in both groups and the comparison was statistically highly significant from the first follow up visit whereas it was statistically significant only at the third follow up visit after sessions.

Table 16:- Comparison between intervention and non intervention group as regard admission to hospital per week during each follow up visit

\begin{tabular}{|c|c|c|c|c|c|c|c|}
\hline & \multicolumn{2}{|c|}{$\begin{array}{l}\text { Non } \\
\text { intervention }\end{array}$} & \multicolumn{3}{|c|}{ Intervention } & \multicolumn{2}{|c|}{ T-test } \\
\hline & $\begin{array}{l}\text { Me } \\
\text { an }\end{array}$ & $\pm \mathrm{SI}$ & $\begin{array}{l}\text { Me } \\
\text { an }\end{array}$ & \pm & & $\mathbf{t}$ & $\begin{array}{l}\text { P- } \\
\text { value }\end{array}$ \\
\hline $\begin{array}{l}\text { Number of times of admission to hospital per week due to asthma } \\
\text { before follow up }\end{array}$ & 0.77 & $\begin{array}{l}0 . \\
\pm \\
\end{array}$ & 0.73 & \pm & $\begin{array}{l}0.3 \\
0\end{array}$ & $\begin{array}{l}0.3 \\
74\end{array}$ & 0.709 \\
\hline $\begin{array}{l}\text { Number of times of admission to hospital per week due to asthma } \\
\text { at } 2 \text { weeks follow up visi }\end{array}$ & 0.67 & $\pm \begin{array}{l}0 . \\
5\end{array}$ & 0.45 & \pm & $\begin{array}{l}0.1 \\
7\end{array}$ & $\begin{array}{l}2.6 \\
84\end{array}$ & $\begin{array}{l}0.008 \\
*\end{array}$ \\
\hline $\begin{array}{l}\text { Number of times of admission to hospital per week due to asthma } \\
\text { at } 4 \text { weeks follow up visit }\end{array}$ & 0.63 & $\pm \begin{array}{l}0 . \\
0\end{array}$ & 0.30 & \pm & $\begin{array}{l}0.1 \\
2\end{array}$ & $\begin{array}{l}2.9 \\
32\end{array}$ & $\begin{array}{l}0.004 \\
*\end{array}$ \\
\hline $\begin{array}{l}\text { Number of times of admission to hospital per week due to asthma } \\
\text { at } 8 \text { weeks follow up visit }\end{array}$ & 0.56 & $\begin{array}{l}0 . \\
1\end{array}$ & 0.26 & \pm & $\begin{array}{l}0.1 \\
3\end{array}$ & $\begin{array}{l}6.6 \\
74 \\
\end{array}$ & $\begin{array}{l}0.000 \\
*\end{array}$ \\
\hline $\begin{array}{l}\text { Number of times of admission to hospital per week due to asthma } \\
\text { at } 12 \text { weeks follow up visit }\end{array}$ & 0.47 & $\begin{array}{r}0 \\
\pm \quad 3 \\
\end{array}$ & 0.17 & \pm & $\begin{array}{l}0.1 \\
8 \\
\end{array}$ & $\begin{array}{l}6.7 \\
80 \\
\end{array}$ & $\begin{array}{l}0.000 \\
*\end{array}$ \\
\hline
\end{tabular}

Non sig. $>0.05$ Sig. $<0.05^{*}$ High sig. $<0.001$

This table shows that reduction of times occurs in both groups but occurs more in the interventional group and it was also noticed that the comparison was significant from the first follow up visit and become highly significant at the end of the follow up period. 


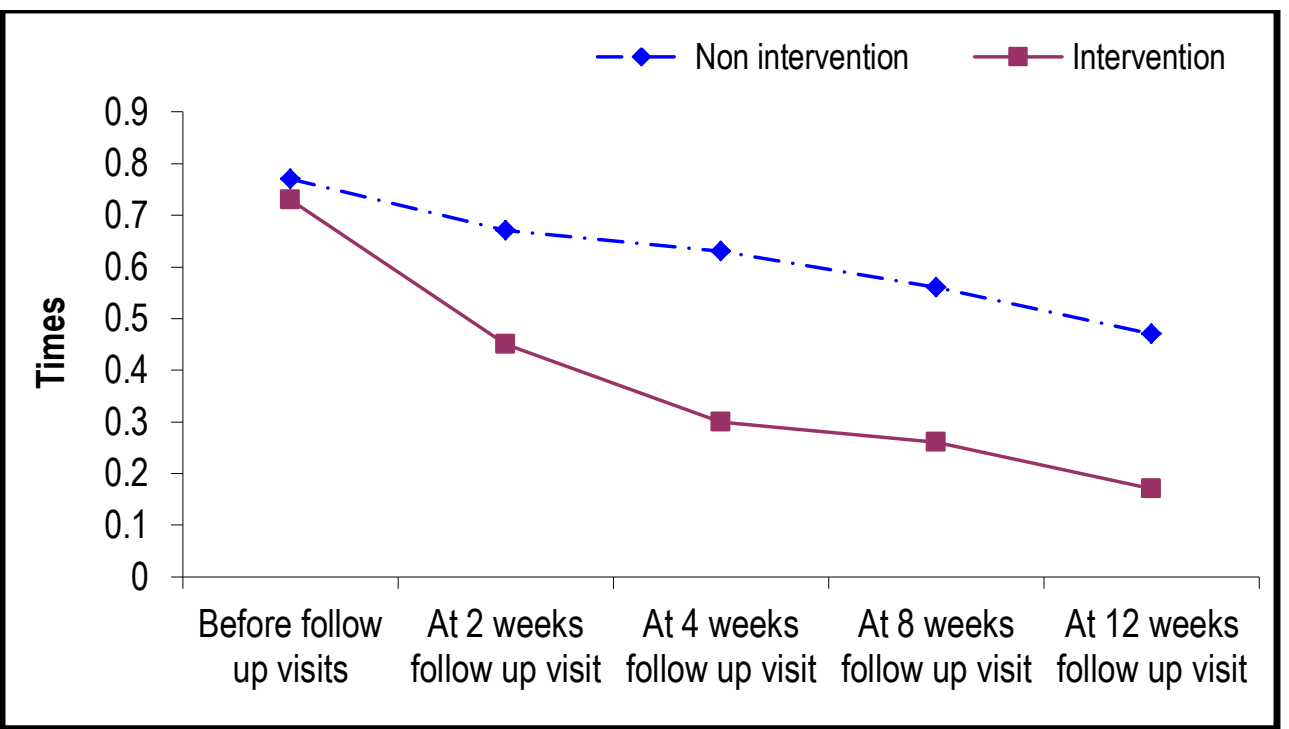

Figure 10:- Occurrence of times of admission to hospital per week during the study period.

Table 17:- Comparison between the difference in number of times of admission to hospital per week due to asthma before follow up and each follow up visit after sessions in both groups.

\begin{tabular}{|c|c|c|}
\hline & $\begin{array}{l}\text { Non } \\
\text { intervention }\end{array}$ & $\begin{array}{l}\text { Interven } \\
\text { tion }\end{array}$ \\
\hline \multicolumn{3}{|l|}{ Paired t-test } \\
\hline $\begin{array}{l}\text { Difference in times of admission to hospital per week due to asthma before follow up } \\
\text { and at } 2 \text { weeks follow up visit. }\end{array}$ & 0.191 & $0.022 *$ \\
\hline $\begin{array}{l}\text { Difference in times of admission to hospital per week due to asthma before follow up } \\
\text { and at } 4 \text { weeks follow up visit }\end{array}$ & 0.069 & $0.000^{*}$ \\
\hline $\begin{array}{l}\text { Difference in times of admission to hospital per week due to asthma before follow up } \\
\text { and at } 8 \text { weeks follow up visit }\end{array}$ & $0.015^{*}$ & $0.001 *$ \\
\hline $\begin{array}{l}\text { Difference in times of admission to hospital per week due to asthma before follow up } \\
\text { and at } 12 \text { weeks follow up visit }\end{array}$ & $0.007 *$ & $0.000^{*}$ \\
\hline
\end{tabular}

Non sig. $>0.05$ Sig. $<0.05^{*}$ High sig. $<0.001$

By using paired t-test this table clarified that the comparison between number of times of admission to hospital per week due to asthma before follow up and each follow up visit after sessions in both groups and the comparison was statistically significant from the first follow up visit and become highly significant in the next follow up visit whereas in the interventional group the comparison was statistically significant only in the third follow up visit.

Table 18:- Comparison between non intervention and intervention groups in eosinophilic count before and after follow up visits.

\begin{tabular}{|l|lll|l|l|l|l|l|}
\hline \multirow{2}{*}{ Eosinophilic count } & \multicolumn{2}{|l|}{ Non intervention } & \multicolumn{2}{l|}{ Intervention } & \multicolumn{3}{l|}{ T-test } \\
\cline { 2 - 10 } & Mean & \pm & SD & Mean & \pm & SD & t & P-value \\
\hline Before follow up visits. & 3.00 & \pm & 1.64 & 2.60 & \pm & 1.66 & 1.082 & 0.282 \\
\hline After follow up visits. & 3.00 & \pm & 1.39 & 1.97 & \pm & 1.37 & 3.346 & $<0.001^{*}$ \\
\hline
\end{tabular}

This table shows that it was reduction in eosinophilic count more in intervention group after follow up visits and there is statistically significance in comparison between groups after follow up visits as regard eosinophilic count. 


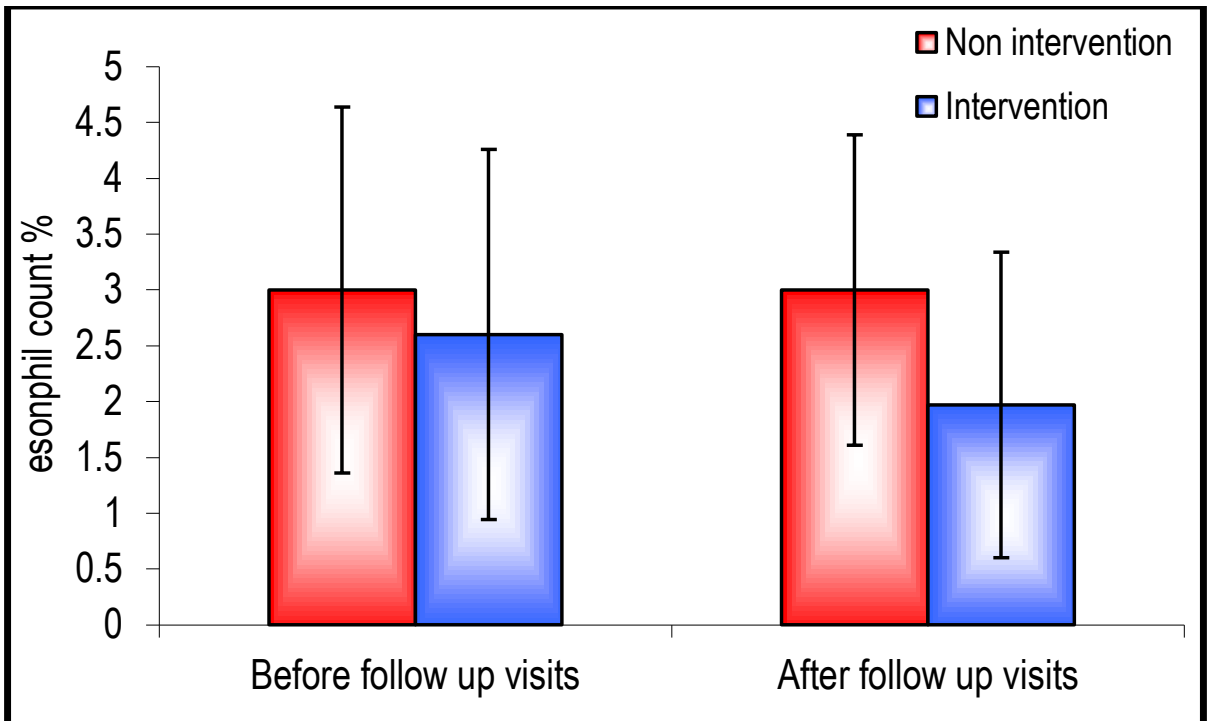

Figure 11:- Comparison between non intervention and intervention groups in eosinophilic count before and after sessions.

Table 19:- Comparison between non intervention and intervention groups in eosinophilic count before and after follow up visits.

\begin{tabular}{|l|l|l|}
\hline Paired t-test & Non intervention & Intervention \\
\hline Difference between esinophilic count before and after follow up visits & 1.000 & $0.048^{*}$ \\
\hline
\end{tabular}

By using paired t-test there is statistically significance in comparison between eosinophilic count in intervention group before and after follow up visits. And no statistically significance in comparison between esinophilic count before and after follow up visits in non intervention group.

Table 20:- The effects of education on asthma control in intervention group using number of days of restricted activities per week due to asthma.

\begin{tabular}{|c|c|c|c|c|c|c|c|c|}
\hline \multirow[t]{3}{*}{ Intervention } & \multicolumn{8}{|c|}{ Education level } \\
\hline & \multicolumn{3}{|c|}{ Illiterate } & \multicolumn{3}{|c|}{ Educated } & \multicolumn{2}{|c|}{ T-test } \\
\hline & $\begin{array}{l}\text { Mea } \\
\text { n }\end{array}$ & \pm & SD & $\begin{array}{l}\text { Mea } \\
\text { n }\end{array}$ & \pm & SD & t & $\begin{array}{l}\text { P- } \\
\text { value }\end{array}$ \\
\hline $\begin{array}{l}\text { Number of days of restricted activities per week before follow } \\
\text { up. }\end{array}$ & 1.90 & \pm & $\begin{array}{l}0.7 \\
9\end{array}$ & 2.11 & \pm & $\begin{array}{l}0.8 \\
3\end{array}$ & $\begin{array}{l}- \\
0.91 \\
2\end{array}$ & 0.365 \\
\hline $\begin{array}{l}\text { Number of days of restricted activities per week at } 2 \text { weeks } \\
\text { follow up visits }\end{array}$ & 0.64 & \pm & $\begin{array}{l}0.5 \\
3\end{array}$ & 0.50 & \pm & $\begin{array}{l}0.5 \\
1\end{array}$ & $\begin{array}{l}0.96 \\
1\end{array}$ & 0.340 \\
\hline $\begin{array}{l}\text { Number of days of restricted activities per week at } 4 \text { weeks } \\
\text { follow up visits }\end{array}$ & 0.67 & \pm & $\begin{array}{l}0.6 \\
5\end{array}$ & 0.78 & \pm & $\begin{array}{l}0.5 \\
5\end{array}$ & $\begin{array}{l}- \\
0.63 \\
4\end{array}$ & 0.529 \\
\hline $\begin{array}{l}\text { Number of days of restricted activities per week at } 8 \text { weeks } \\
\text { follow up visits }\end{array}$ & 0.31 & \pm & $\begin{array}{l}0.4 \\
7\end{array}$ & 0.50 & \pm & $\begin{array}{l}0.5 \\
1\end{array}$ & $\begin{array}{l}- \\
1.40 \\
3\end{array}$ & 0.166 \\
\hline $\begin{array}{l}\text { Number of days of restricted activities per week at } 12 \text { weeks } \\
\text { follow up visits }\end{array}$ & 0.26 & \pm & $\begin{array}{l}0.4 \\
5\end{array}$ & 0.33 & \pm & $\begin{array}{l}0.4 \\
9\end{array}$ & $\begin{array}{l} \\
0.55 \\
5\end{array}$ & 0.581 \\
\hline
\end{tabular}

This table shows the effects of education on asthma control in intervention group using number of days of restricted activities per week due to asthma. It was noticed that no statistically significance in comparison between both subgroups (the illiterate \& educated parents). 


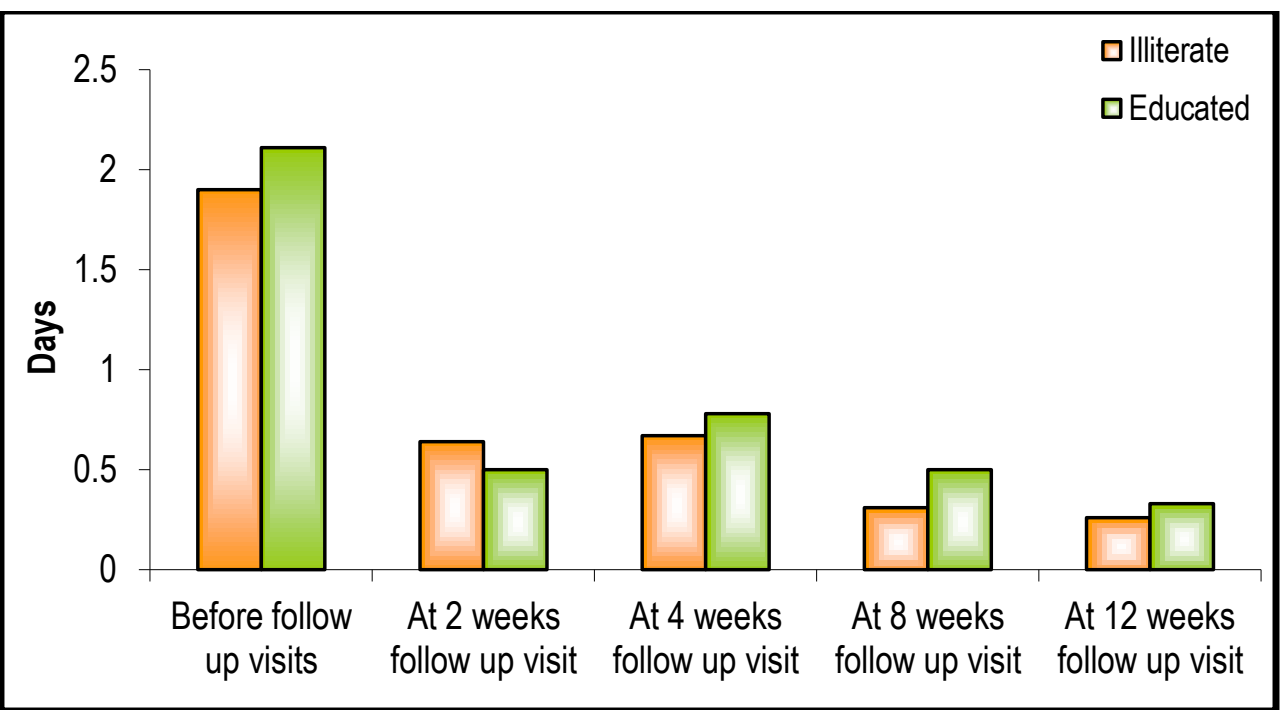

Figure 12:- The effects of education on asthma control in intervention group using number of days of restricted activities per week due to asthma.

Table 21:- The effects of education on asthma control in intervention group using number of days of absence of school per week due to asthma.

\begin{tabular}{|c|c|c|c|c|c|c|c|c|}
\hline \multirow[t]{3}{*}{ Intervention } & \multicolumn{8}{|c|}{ Education level } \\
\hline & \multicolumn{3}{|c|}{ Illiterate } & \multicolumn{3}{|c|}{ Educated } & \multicolumn{2}{|c|}{ T-test } \\
\hline & $\begin{array}{l}\text { Mea } \\
\text { n }\end{array}$ & \pm & SD & $\begin{array}{l}\text { Mea } \\
\text { n }\end{array}$ & \pm & SD & $\mathbf{t}$ & $\begin{array}{l}\text { P- } \\
\text { value }\end{array}$ \\
\hline $\begin{array}{l}\text { Number of days of absence from school before follow up } \\
\text { visits }\end{array}$ & 2.12 & \pm & $\begin{array}{l}0.6 \\
7\end{array}$ & 2.17 & \pm & $\begin{array}{l}0.7 \\
1\end{array}$ & $\overline{-}-248$ & 0.805 \\
\hline $\begin{array}{l}\text { Number of days of absence from school at } 2 \text { weeks follow } \\
\text { up visit }\end{array}$ & 0.95 & \pm & $\begin{array}{l}0.7 \\
6\end{array}$ & 1.06 & \pm & $\begin{array}{l}0.9 \\
4\end{array}$ & 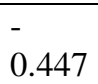 & 0.656 \\
\hline $\begin{array}{l}\text { Number of days of absence from school at } 4 \text { weeks follow } \\
\text { up visit }\end{array}$ & 0.52 & \pm & $\begin{array}{l}0.5 \\
1\end{array}$ & 0.44 & \pm & $\begin{array}{l}0.6 \\
2\end{array}$ & 0.522 & 0.604 \\
\hline $\begin{array}{l}\text { Number of days of absence from school at } 8 \text { weeks follow } \\
\text { up visit }\end{array}$ & 0.45 & \pm & $\begin{array}{l}0.5 \\
9\end{array}$ & 0.39 & \pm & $\begin{array}{l}0.5 \\
0\end{array}$ & 0.397 & 0.693 \\
\hline $\begin{array}{l}\text { Number of days of absence from school at } 12 \text { weeks } \\
\text { follow up visit }\end{array}$ & 0.24 & \pm & $\begin{array}{ll}0.4 \\
3\end{array}$ & 0.28 & \pm & $\begin{array}{l}0.4 \\
6\end{array}$ & $\overline{-}-320$ & 0.750 \\
\hline
\end{tabular}

This table shows that no statistically significance in comparison between both subgroups. 


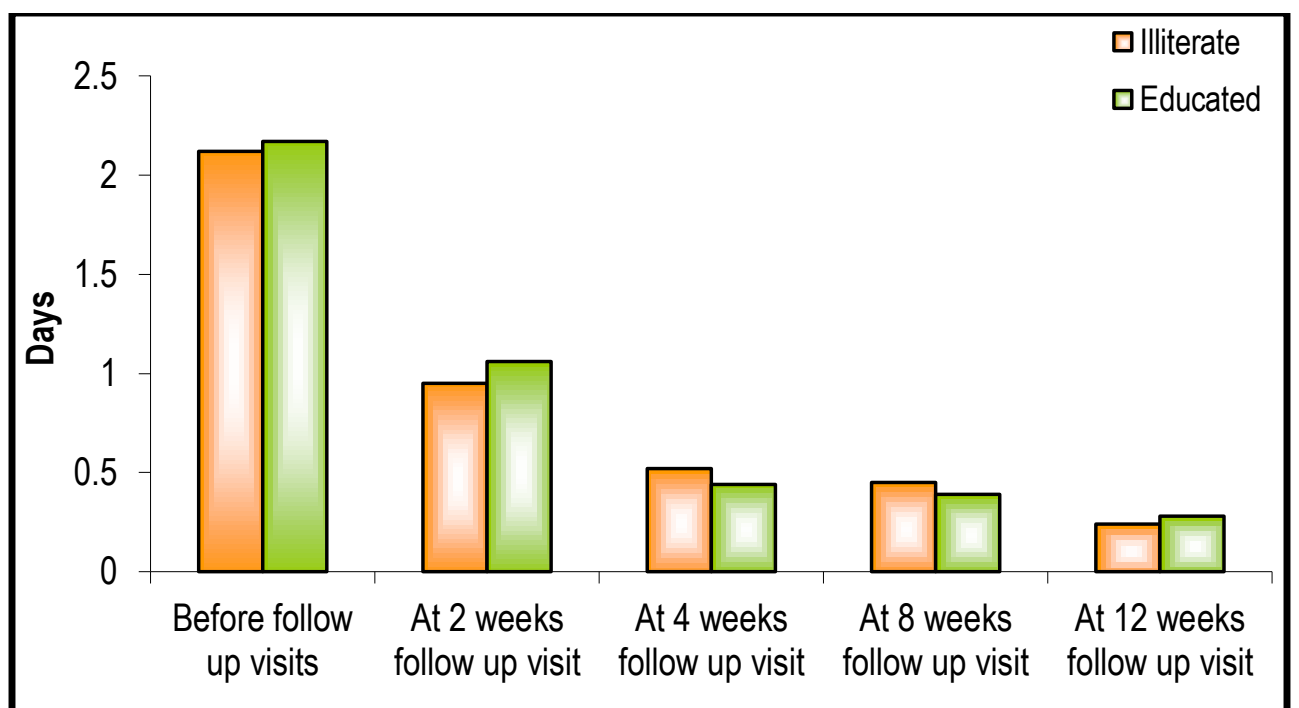

Figure 13:- Effects of education on level of control using number of days of restricted activities per week.

Table 22:- The effects of education on asthma control in intervention group using number of E.D. visits per week due to asthma

\begin{tabular}{|c|c|c|c|c|c|c|c|c|}
\hline \multirow[t]{3}{*}{ Intervention } & \multicolumn{8}{|c|}{ Education level } \\
\hline & \multicolumn{3}{|c|}{ Illiterate } & \multicolumn{3}{|c|}{ Educated } & \multicolumn{2}{|c|}{ T-test } \\
\hline & $\begin{array}{l}\text { Me } \\
\text { an }\end{array}$ & \pm & $\begin{array}{l}\text { S } \\
\mathbf{D}\end{array}$ & $\begin{array}{l}\text { Me } \\
\text { an }\end{array}$ & \pm & $\begin{array}{l}\text { S } \\
\mathbf{D}\end{array}$ & $\mathbf{t}$ & $\begin{array}{l}\text { P- } \\
\text { valu } \\
\text { e }\end{array}$ \\
\hline $\begin{array}{l}\text { Number of times of E.D. visits per week due to asthma before } \\
\text { follow up visits }\end{array}$ & $\begin{array}{l}2.0 \\
2\end{array}$ & \pm & $\begin{array}{l}0 . \\
68\end{array}$ & $\begin{array}{l}1.9 \\
4\end{array}$ & \pm & $\begin{array}{l}0 . \\
73\end{array}$ & $\begin{array}{l}0.4 \\
06\end{array}$ & $\begin{array}{l}0.68 \\
6\end{array}$ \\
\hline $\begin{array}{l}\text { Difference in number of days of restricted activities before follow } \\
\text { up and at } 2 \text { weeks follow up visit. }\end{array}$ & $\begin{array}{l}0.6 \\
4\end{array}$ & \pm & $\begin{array}{l}0 . \\
48\end{array}$ & $\begin{array}{l}0.7 \\
2\end{array}$ & \pm & $\begin{array}{l}0 . \\
57\end{array}$ & $\begin{array}{l}- \\
0.5 \\
49\end{array}$ & $\begin{array}{l}0.58 \\
5\end{array}$ \\
\hline $\begin{array}{l}\text { Difference in number of days of restricted activities before follow } \\
\text { up and at } 4 \text { weeks follow up visit. }\end{array}$ & $\begin{array}{l}0.4 \\
8\end{array}$ & \pm & $\begin{array}{l}0 . \\
55\end{array}$ & $\begin{array}{l}0.6 \\
7\end{array}$ & \pm & $\begin{array}{l}0 . \\
49\end{array}$ & $\begin{array}{l}- \\
1.2 \\
69\end{array}$ & $\begin{array}{l}0.21 \\
0\end{array}$ \\
\hline $\begin{array}{l}\text { Difference in number of days of restricted activities before follow } \\
\text { up and at } 8 \text { weeks follow up visit. }\end{array}$ & $\begin{array}{l}0.5 \\
5\end{array}$ & \pm & $\begin{array}{l}0 . \\
59\end{array}$ & $\begin{array}{l}0.5 \\
6\end{array}$ & \pm & $\begin{array}{l}0 . \\
51\end{array}$ & $\begin{array}{l}- \\
0.0 \\
49\end{array}$ & $\begin{array}{l}0.96 \\
1\end{array}$ \\
\hline $\begin{array}{l}\text { Difference in number of days of restricted activities before follow } \\
\text { up and at } 12 \text { weeks follow up visit. }\end{array}$ & $\begin{array}{ll}0.4 \\
5\end{array}$ & \pm & $\begin{array}{l}0 . \\
50\end{array}$ & $\begin{array}{ll}0.3 \\
3 \\
\end{array}$ & \pm & $\begin{array}{l}0 . \\
49\end{array}$ & $\begin{array}{l}0.8 \\
48\end{array}$ & $\begin{array}{l}0.40 \\
0\end{array}$ \\
\hline
\end{tabular}

This table shows that no statistically significance in comparison between both subgroups. 


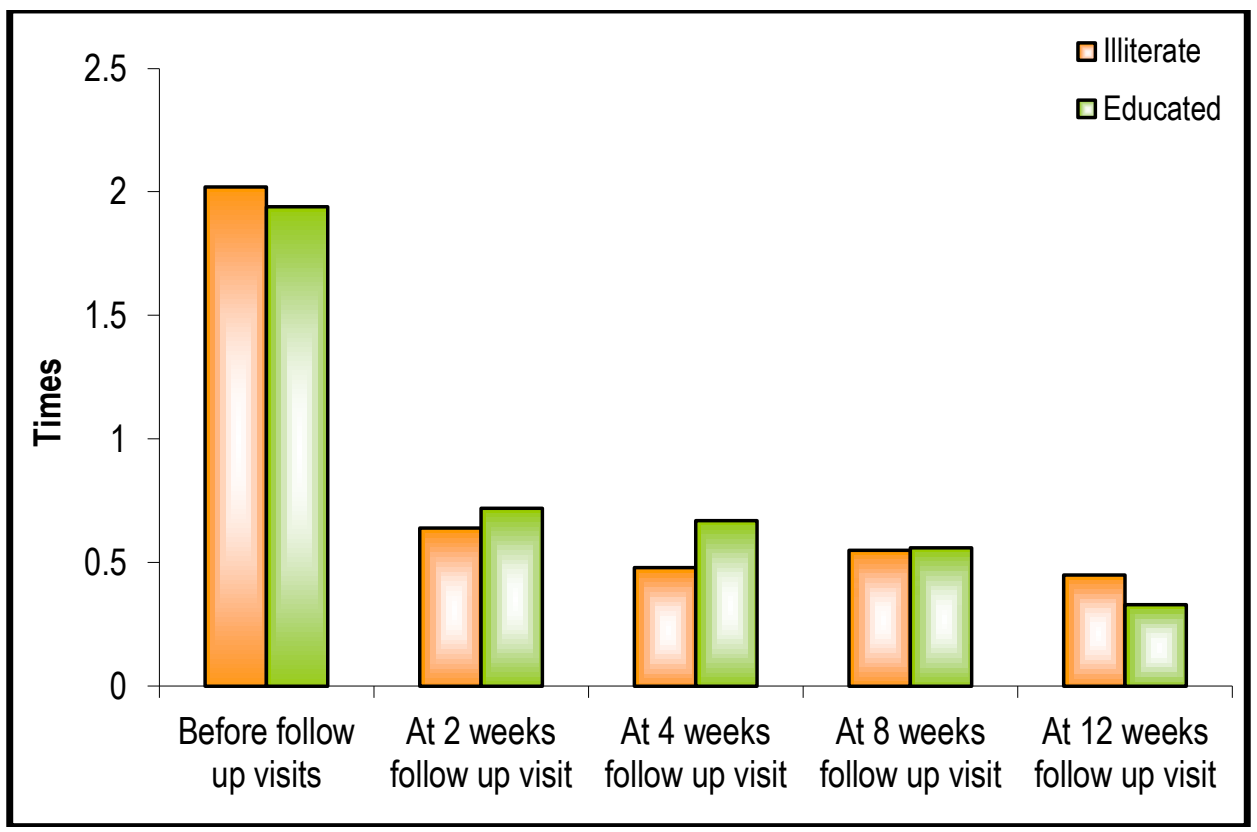

Figure 14:- Shows effect of education on asthma control in intervention group using E.D. visits per week due to asthma.

Table 23:- The effects of education on level of control using times of rescue therapy per week before the sessions \& during the follow up visits

\begin{tabular}{|c|c|c|c|c|c|c|c|c|}
\hline \multirow{3}{*}{ Intervention } & \multicolumn{8}{|c|}{ Education level } \\
\hline & \multicolumn{3}{|c|}{ Illiterate } & \multicolumn{3}{|c|}{ Educated } & \multicolumn{2}{|l|}{ T-test } \\
\hline & $\begin{array}{l}\text { Mea } \\
\text { n }\end{array}$ & \pm & SD & $\begin{array}{l}\text { Mea } \\
\text { n }\end{array}$ & \pm & SD & t & $\begin{array}{l}\text { P- } \\
\text { value }\end{array}$ \\
\hline $\begin{array}{l}\text { Number of times of use of rescue therapy before follow up } \\
\text { visits }\end{array}$ & 6.12 & \pm & $\begin{array}{l}1.2 \\
1\end{array}$ & 6.39 & \pm & $\begin{array}{l}1.2 \\
4\end{array}$ & $-\overline{0}-784$ & 0.437 \\
\hline $\begin{array}{l}\text { Number of times of use of rescue therapy at } 2 \text { weeks follow } \\
\text { up visit }\end{array}$ & 1.00 & \pm & $\begin{array}{l}0.7 \\
1\end{array}$ & 1.06 & \pm & $\begin{array}{l}0.8 \\
7\end{array}$ & $\overline{0}-258$ & 0.797 \\
\hline $\begin{array}{l}\text { Number of times of use of rescue therapy at } 4 \text { weeks follow } \\
\text { up visit }\end{array}$ & 0.95 & \pm & $\begin{array}{l}0.6 \\
2\end{array}$ & 0.83 & \pm & $\begin{array}{l}0.7 \\
9\end{array}$ & 0.626 & 0.534 \\
\hline $\begin{array}{l}\text { Number of times of use of rescue therapy at } 8 \text { weeks follow } \\
\text { up visit }\end{array}$ & 0.98 & \pm & $\begin{array}{l}0.6 \\
8\end{array}$ & 0.83 & \pm & $\begin{array}{ll}0.7 \\
1\end{array}$ & 0.737 & 0.464 \\
\hline $\begin{array}{l}\text { Number of times of use of rescue therapy at } 12 \text { weeks } \\
\text { follow up visit }\end{array}$ & 0.57 & \pm & $\begin{array}{l}0.6 \\
7\end{array}$ & 0.61 & \pm & $\begin{array}{l}0.6 \\
1\end{array}$ & $-\overline{0}-216$ & 0.829 \\
\hline
\end{tabular}

This table shows that no statistically significance in comparison between subgroups. 


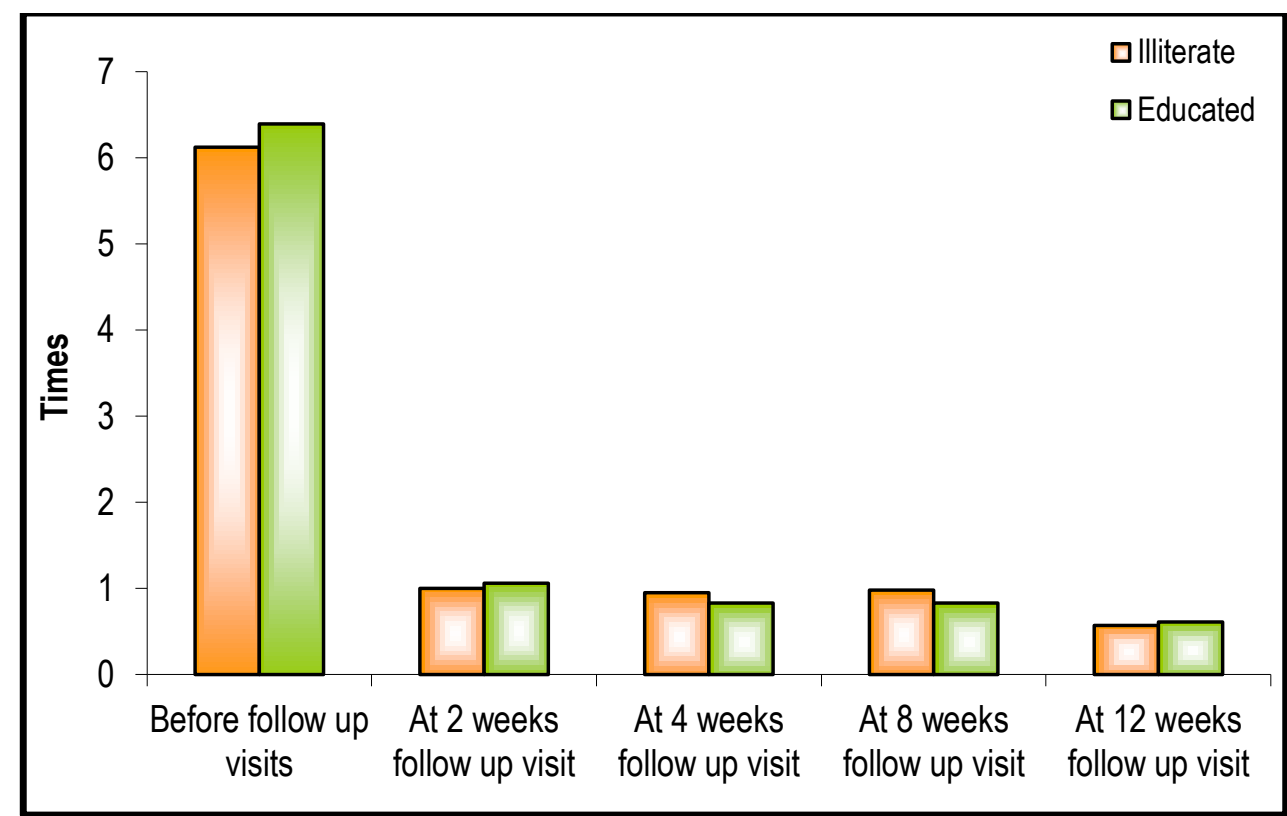

Figure 15:- Effects of education on level of control using times of rescue therapy per week.

Table 24:- The effects of education on asthma control using number of night disturbance per week due to asthma before the sessions \& during the follow up visits.

\begin{tabular}{|c|c|c|c|c|c|c|c|c|}
\hline \multirow[t]{3}{*}{ Intervention } & \multicolumn{8}{|c|}{ Education level } \\
\hline & \multicolumn{3}{|c|}{ Illiterate } & \multicolumn{3}{|c|}{ Educated } & \multicolumn{2}{|c|}{ T-test } \\
\hline & $\begin{array}{l}\text { Mea } \\
\text { n }\end{array}$ & \pm & SD & $\begin{array}{l}\text { Mea } \\
\text { n }\end{array}$ & \pm & SD & $\mathbf{t}$ & $\begin{array}{l}\text { P- } \\
\text { value }\end{array}$ \\
\hline $\begin{array}{l}\text { Number of night disturbance per week due to asthma before } \\
\text { follow up visits }\end{array}$ & 2.05 & \pm & $\begin{array}{l}0.7 \\
3\end{array}$ & 2.33 & \pm & $\begin{array}{l}0.7 \\
7\end{array}$ & $\begin{array}{l}- \\
1.36 \\
7\end{array}$ & 0.177 \\
\hline $\begin{array}{l}\text { Number of night disturbance per week due to asthma at } 2 \\
\text { weeks follow up visits }\end{array}$ & 0.88 & \pm & $\begin{array}{l}0.7 \\
7\end{array}$ & 0.83 & \pm & $\begin{array}{l}0.7 \\
1\end{array}$ & $\begin{array}{l}0.22 \\
4\end{array}$ & 0.823 \\
\hline $\begin{array}{l}\text { Number of night disturbance per week due to asthma at } 4 \\
\text { weeks follow up visits }\end{array}$ & 0.60 & \pm & $\begin{array}{l}0.5 \\
9\end{array}$ & 0.39 & \pm & $\begin{array}{l}0.6 \\
1\end{array}$ & $\begin{array}{l}1.23 \\
5\end{array}$ & 0.222 \\
\hline $\begin{array}{l}\text { Number of night disturbance per week due to asthma at } 8 \text { weeks } \\
\text { follow up visits }\end{array}$ & 0.40 & \pm & $\begin{array}{l}0.5 \\
4\end{array}$ & 0.39 & \pm & $\begin{array}{l}0.5 \\
0\end{array}$ & $\begin{array}{l}0.10 \\
6\end{array}$ & 0.916 \\
\hline $\begin{array}{l}\text { Number of night disturbance per week due to asthma at } 12 \\
\text { weeks follow up visits }\end{array}$ & 0.21 & \pm & $\begin{array}{ll}0.4 \\
7\end{array}$ & 0.33 & \pm & $\begin{array}{l}0.4 \\
9\end{array}$ & $\begin{array}{l}-\bar{l} \\
0.89 \\
0\end{array}$ & 0.377 \\
\hline
\end{tabular}

This table that no statistically significance in comparison between subgroups. 


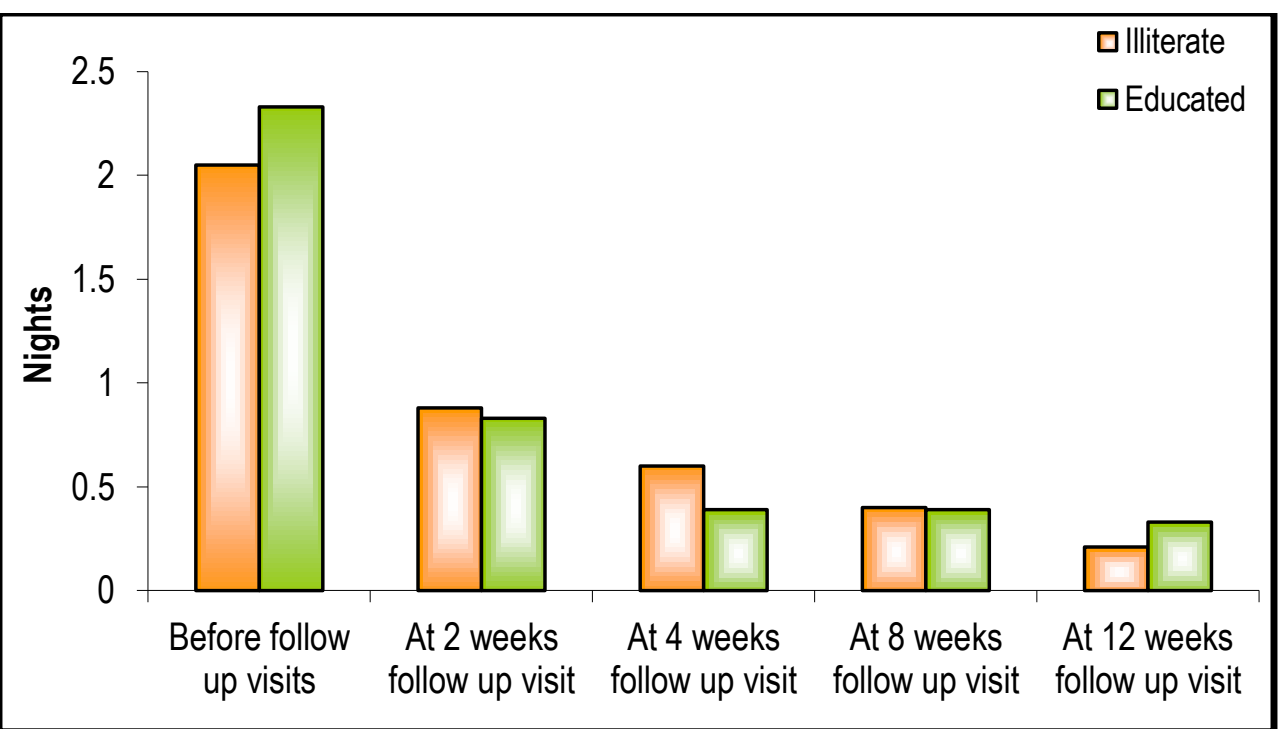

Figure 16:- The effects of education on asthma control using number of night disturbance per week due to asthma.

Table 25:- The effects of education on asthma control in interventional group using times of admission to hospital per week due to asthma before the sessions \& during the follow up visits.

\begin{tabular}{|c|c|c|c|c|c|c|c|c|}
\hline \multirow[t]{3}{*}{ Intervention } & \multicolumn{8}{|c|}{ Education level } \\
\hline & \multicolumn{3}{|c|}{ Illiterate } & \multicolumn{3}{|c|}{ Educated } & \multicolumn{2}{|c|}{ T-test } \\
\hline & $\begin{array}{l}\text { Me } \\
\text { an }\end{array}$ & \pm & $\begin{array}{l}\text { S } \\
\text { D }\end{array}$ & $\begin{array}{l}\text { Me } \\
\text { an }\end{array}$ & \pm & $\begin{array}{l}\text { S } \\
\mathbf{D}\end{array}$ & $\mathbf{t}$ & $\begin{array}{l}\text { P- } \\
\text { value }\end{array}$ \\
\hline $\begin{array}{l}\text { Number of times of admission to hospital per week due to asthma } \\
\text { before follow up visits. }\end{array}$ & 0.50 & \pm & $\begin{array}{l}0.5 \\
1\end{array}$ & 0.61 & \pm & $\begin{array}{l}0.5 \\
0\end{array}$ & $\begin{array}{l}- \\
0.78 \\
1\end{array}$ & 0.438 \\
\hline $\begin{array}{l}\text { Number of times of admission to hospital per week due to asthma } \\
\text { at } 2 \text { weeks follow up visit }\end{array}$ & 0.31 & \pm & $\begin{array}{l}0.4 \\
7\end{array}$ & 0.33 & \pm & $\begin{array}{l}0.4 \\
9\end{array}$ & $\begin{array}{l}- \\
0.17 \\
9\end{array}$ & 0.859 \\
\hline $\begin{array}{l}\text { Number of times of admission to hospital per week due to asthma } \\
\text { at } 4 \text { weeks follow up visit }\end{array}$ & 0.21 & \pm & $\begin{array}{l}0.4 \\
2\end{array}$ & 0.22 & \pm & $\begin{array}{l}0.4 \\
3\end{array}$ & $\begin{array}{l}- \\
0.06 \\
7\end{array}$ & 0.947 \\
\hline $\begin{array}{l}\text { Number of times of admission to hospital per week due to asthma } \\
\text { at } 8 \text { weeks follow up visit }\end{array}$ & 0.14 & \pm & $\begin{array}{l}0.3 \\
5\end{array}$ & 0.44 & \pm & $\begin{array}{l}0.5 \\
1\end{array}$ & $\begin{array}{l}- \\
2.63 \\
3\end{array}$ & 0.011 \\
\hline $\begin{array}{l}\text { Number of times of admission to hospital per week due to asthma } \\
\text { at } 12 \text { weeks follow up visit }\end{array}$ & 0.14 & \pm & $\begin{array}{l}0.3 \\
5\end{array}$ & 0.22 & \pm & $\begin{array}{l}0.4 \\
3\end{array}$ & $\begin{array}{l}- \\
0.74 \\
7\end{array}$ & 0.458 \\
\hline
\end{tabular}

This table shows that no statistically significance in comparison between subgroups. 


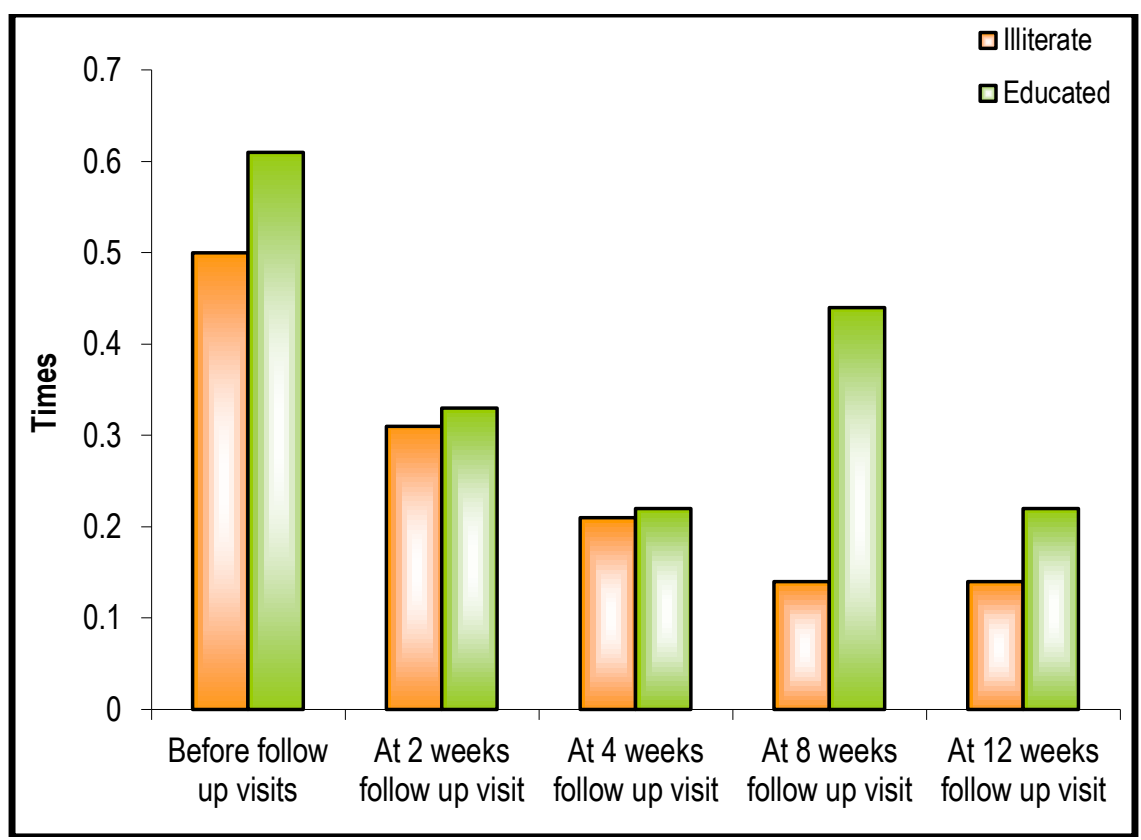

Figure 17:- The effects of education on asthma control in interventional group using times of admission to hospital per week due to asthma.

Table 26:- The effects of education on asthma control level in intervention group using eosinophilic count

\begin{tabular}{|c|c|c|c|c|c|c|c|c|}
\hline \multirow[t]{3}{*}{ Intervention } & \multicolumn{8}{|c|}{ Education level } \\
\hline & \multicolumn{3}{|c|}{ Illiterate } & \multicolumn{3}{|c|}{ Educated } & \multicolumn{2}{|l|}{ T-test } \\
\hline & Mean & \pm & SD & Mean & \pm & SD & t & P-value \\
\hline Eosinophilic count before follow up visits. & 2.62 & \pm & 1.77 & 2.56 & \pm & 1.42 & 0.135 & 0.893 \\
\hline Eosinophilic count after follow up visits. & 2.00 & \pm & 1.43 & 1.89 & \pm & 1.23 & 0.287 & 0.775 \\
\hline
\end{tabular}

This table shows the effects of education on asthma control level in intervention group using eosinophilic count. It was noticed that no statistically significance in comparison between subgroups.

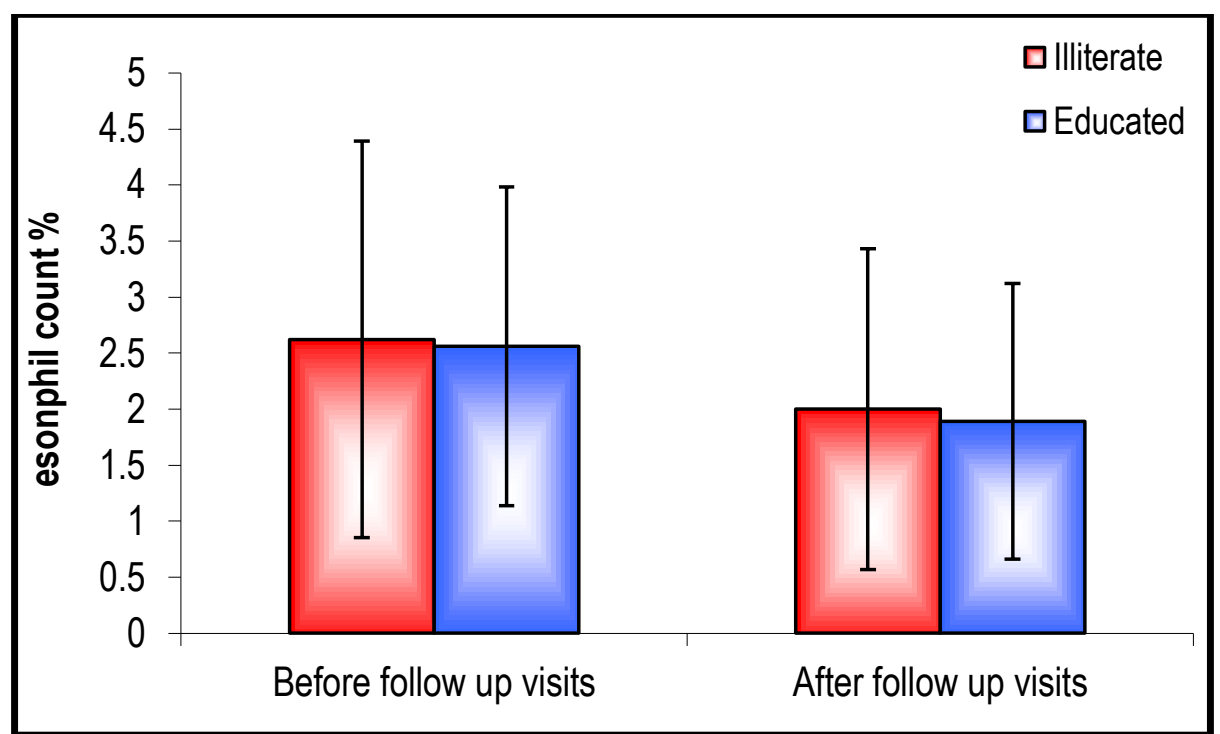

Figure 18:- The effects of education on asthma control level in intervention group using eosinophilic count 
Table 27:- Comparison between subgroups of intervention group as regard number of days of restricted activities per week due to asthma among the groups before and during the follow up visits

\begin{tabular}{|c|c|c|c|c|c|c|c|c|c|c|c|}
\hline \multirow[t]{3}{*}{ Intervention } & \multicolumn{11}{|c|}{ Age } \\
\hline & \multicolumn{3}{|c|}{ 6m-5years } & \multicolumn{3}{|c|}{$\begin{array}{l}>5 y \\
\text { 8years }\end{array}$} & \multicolumn{3}{|c|}{$\begin{array}{l}>8 y \\
12 \text { years }\end{array}$} & \multicolumn{2}{|c|}{ ANOVA } \\
\hline & $\begin{array}{l}\text { Me } \\
\text { an }\end{array}$ & \pm & $\begin{array}{l}\text { S } \\
\mathbf{D}\end{array}$ & $\begin{array}{l}\text { Me } \\
\text { an }\end{array}$ & \pm & $\begin{array}{l}\text { S } \\
\mathbf{D}\end{array}$ & $\begin{array}{l}\text { Me } \\
\text { an }\end{array}$ & \pm & $\begin{array}{l}\mathbf{S} \\
\mathbf{D}\end{array}$ & f & $\begin{array}{l}\text { P- } \\
\text { valu } \\
\text { e }\end{array}$ \\
\hline $\begin{array}{l}\text { Number of days of restricted activities per week } \\
\text { before follow up. }\end{array}$ & $\begin{array}{l}1.9 \\
5\end{array}$ & \pm & $\begin{array}{l}0 . \\
83\end{array}$ & $\begin{array}{l}2.0 \\
0\end{array}$ & \pm & $\begin{array}{l}0 . \\
82\end{array}$ & $\begin{array}{l}1.9 \\
5\end{array}$ & \pm & $\begin{array}{l}0 . \\
80\end{array}$ & $\begin{array}{l}0.0 \\
23\end{array}$ & $\begin{array}{l}0.97 \\
7\end{array}$ \\
\hline $\begin{array}{l}\text { Number of days of restricted activities per week at } \\
2 \text { weeks follow up visits }\end{array}$ & $\begin{array}{l}0.5 \\
5\end{array}$ & \pm & $\begin{array}{l}0 . \\
51\end{array}$ & $\begin{array}{l}0.5 \\
8\end{array}$ & \pm & $\begin{array}{l}0 . \\
51\end{array}$ & $\begin{array}{ll}0.6 \\
7\end{array}$ & \pm & $\begin{array}{ll}0 . \\
58\end{array}$ & $\begin{array}{l}0.2 \\
66\end{array}$ & $\begin{array}{ll}0.76 \\
7\end{array}$ \\
\hline $\begin{array}{l}\text { Number of days of restricted activities per week at } \\
\text { 4weeks follow up visits }\end{array}$ & $\begin{array}{l}1.0 \\
0\end{array}$ & \pm & $\begin{array}{l}0 . \\
73\end{array}$ & $\begin{array}{l}0.5 \\
8\end{array}$ & \pm & $\begin{array}{l}0 . \\
51\end{array}$ & $\begin{array}{l}0.5 \\
2\end{array}$ & \pm & $\begin{array}{l}0 . \\
51\end{array}$ & $\begin{array}{l}3.9 \\
16\end{array}$ & $\begin{array}{l}0.02 \\
5\end{array}$ \\
\hline $\begin{array}{l}\text { Number of days of restricted activities per week at } 8 \\
\text { weeks follow up visits }\end{array}$ & $\begin{array}{l}0.3 \\
0\end{array}$ & \pm & $\begin{array}{l}0 . \\
47\end{array}$ & $\begin{array}{l}0.3 \\
2\end{array}$ & \pm & $\begin{array}{l}0 . \\
48\end{array}$ & $\begin{array}{l}0.4 \\
8\end{array}$ & \pm & $\begin{array}{l}0 . \\
51\end{array}$ & $\begin{array}{l}0.8 \\
21\end{array}$ & $\begin{array}{l}0.44 \\
5\end{array}$ \\
\hline $\begin{array}{l}\text { Number of days of restricted activities per week at } 1 \\
2 \text { weeks follow up visits }\end{array}$ & $\begin{array}{l}0.1 \\
5\end{array}$ & \pm & $\begin{array}{l}0 . \\
37\end{array}$ & $\begin{array}{l}0.2 \\
6\end{array}$ & \pm & $\begin{array}{l}0 . \\
45\end{array}$ & $\begin{array}{l}0.4 \\
3\end{array}$ & \pm & $\begin{array}{l}0 . \\
51\end{array}$ & $\begin{array}{l}2.0 \\
20\end{array}$ & $\begin{array}{l}0.14 \\
2\end{array}$ \\
\hline
\end{tabular}

This table shows that no statistically significant in comparison between subgroups (B1, B2, B3).

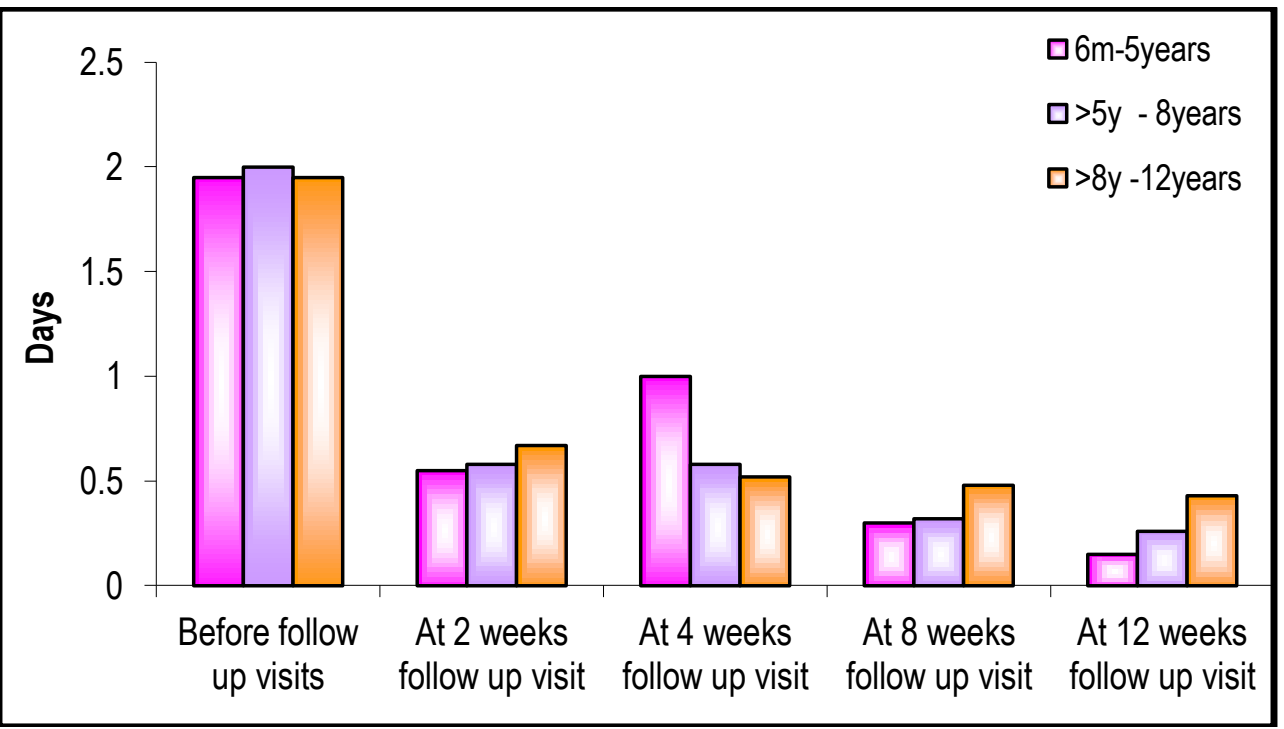

Figure 19:- Comparison between the subgroups of intervention group as regard number of days of restricted activities due to asthma among the groups before and during the follow up visits.

Table 28:- Comparison between the difference in the number of days of restricted activities per week due to asthma before follow up and at each follow up visit in all subgroups

\begin{tabular}{|c|c|c|c|}
\hline & $\begin{array}{l}\text { 6m- } \\
\text { 5years }\end{array}$ & $\begin{array}{l}5 y \\
\text { 8years }\end{array}$ & $\begin{array}{l}8 y \\
\text { 12years }\end{array}$ \\
\hline \multicolumn{4}{|l|}{ Paired t-test } \\
\hline $\begin{array}{l}\text { Difference in number of days of restricted activities before follow up and at } \\
2 \text { weeks follow up visit. }\end{array}$ & 0.000 & 0.000 & 0.000 \\
\hline $\begin{array}{l}\text { Difference in number of days of restricted activities before follow up and at } \\
4 \text { weeks follow up visit. }\end{array}$ & 0.001 & 0.000 & 0.000 \\
\hline $\begin{array}{l}\text { Difference in number of days of restricted activities before follow up and at } \\
8 \text { weeks follow up visit. }\end{array}$ & 0.000 & 0.000 & 0.000 \\
\hline $\begin{array}{l}\text { Difference in number of days of restricted activities before follow up and at } \\
12 \text { weeks follow up visit. }\end{array}$ & 0.000 & 0.000 & 0.000 \\
\hline
\end{tabular}


By using paired t-test this table shows comparison between number of days of restricted activities per week due to asthma before follow up and at each follow up visit in all subgroups (B1, B2, B3) and it was noticed that no statistically significance in comparison in all subgroups .

Table 29:- Comparison between the subgroups of the intervention group as regard number of days of absence from school per week due to asthma before and during the follow up visits

\begin{tabular}{|c|c|c|c|c|c|c|c|c|c|c|}
\hline \multirow{3}{*}{ Intervention } & \multicolumn{10}{|l|}{ Age } \\
\hline & \multicolumn{2}{|c|}{$6 \mathrm{~m}-5$ years } & \multicolumn{3}{|c|}{$>5$ - 8years } & \multicolumn{3}{|c|}{$>8$-12years } & \multicolumn{2}{|c|}{ ANOVA } \\
\hline & $\begin{array}{l}\text { Me } \\
\text { an }\end{array}$ & \pm SI & $\begin{array}{l}\text { Me } \\
\text { an }\end{array}$ & \pm & SD & $\begin{array}{l}\text { Me } \\
\text { an }\end{array}$ & & SD & $\mathbf{f}$ & $\begin{array}{l}\text { P- } \\
\text { value }\end{array}$ \\
\hline $\begin{array}{l}\text { Number of days of absence from school before } \\
\text { follow up visits. }\end{array}$ & 1.95 & $\begin{array}{l}0.7 \\
\pm \quad 6\end{array}$ & 2.16 & \pm & $\begin{array}{l}0.6 \\
0\end{array}$ & 2.29 & \pm & $\begin{array}{l}0.6 \\
4\end{array}$ & $\begin{array}{l}1.29 \\
6\end{array}$ & 0.282 \\
\hline $\begin{array}{l}\text { Number of days of absence from school at } 2 \\
\text { weeks follow up visit }\end{array}$ & 1.90 & $\begin{array}{ll} & 0.2 \\
\pm \quad 5 \\
\end{array}$ & 0.58 & \pm & $\begin{array}{l}0.5 \\
1\end{array}$ & 0.48 & & $\begin{array}{l}0.5 \\
1\end{array}$ & $\begin{array}{l}52.7 \\
77\end{array}$ & 0.000 \\
\hline $\begin{array}{l}\text { Number of days of absence from school at } 4 \\
\text { weeks follow up visit }\end{array}$ & 0.85 & $\begin{array}{l}0 .< \\
\pm \quad 9 \\
\end{array}$ & 0.37 & \pm & $\begin{array}{l}0.5 \\
0\end{array}$ & 0.29 & & $\begin{array}{l}0.4 \\
6\end{array}$ & $\begin{array}{l}8.04 \\
7\end{array}$ & 0.001 \\
\hline $\begin{array}{l}\text { Number of days of absence from school at } 8 \\
\text { weeks follow up visit }\end{array}$ & 0.70 & $\begin{array}{l}0.6 \\
\pm \quad 6\end{array}$ & 0.26 & \pm & $\begin{array}{l}0.4 \\
5\end{array}$ & 0.33 & & $\begin{array}{l}0.4 \\
8\end{array}$ & $\begin{array}{l}3.75 \\
8\end{array}$ & 0.029 \\
\hline $\begin{array}{l}\text { Number of days of absence from school at } 12 \\
\text { weeks follow up visit }\end{array}$ & 0.35 & $\begin{array}{l}0.4 \\
\pm \quad 9\end{array}$ & 0.00 & \pm & $\begin{array}{l}0.0 \\
0\end{array}$ & 0.38 & & $\begin{array}{l}0.5 \\
0\end{array}$ & $\begin{array}{l}5.24 \\
2\end{array}$ & 0.008 \\
\hline
\end{tabular}

This table shows that no statistically significant in comparison between subgroups (B1, B2, B3).

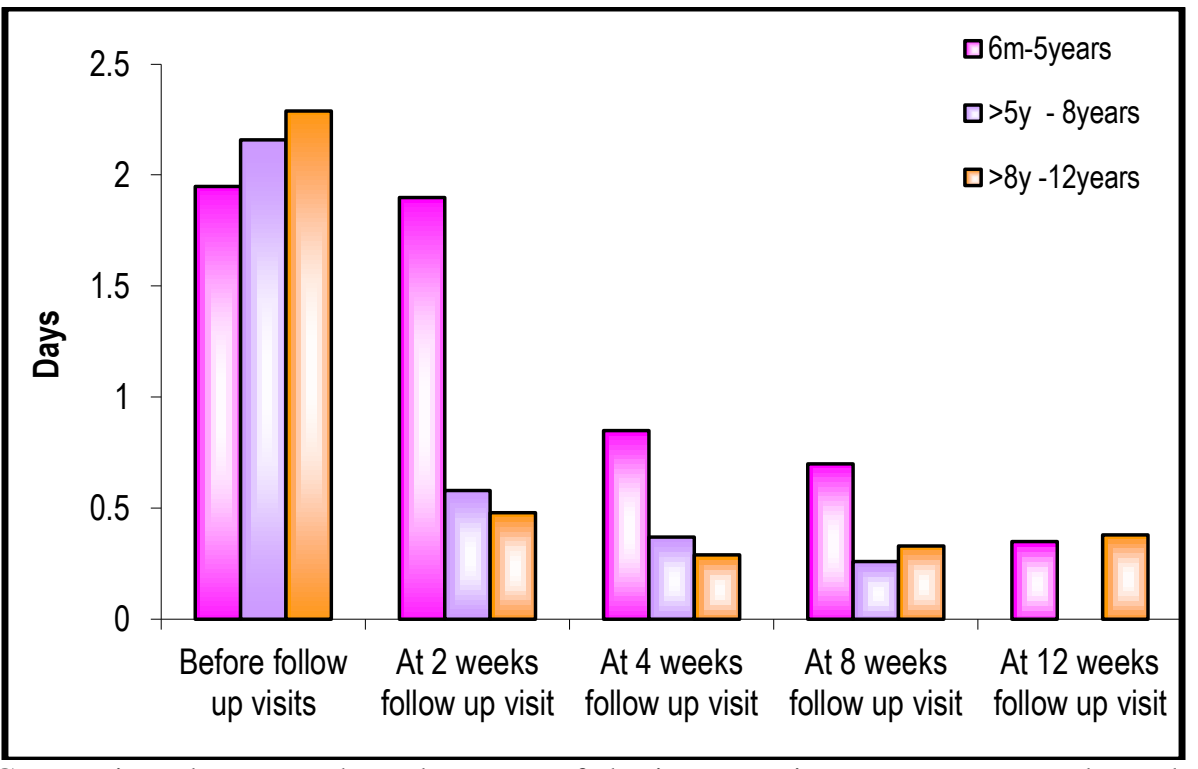

Figure 20:- Comparison between the subgroups of the intervention group as regard number of days of absence from school per week due to asthma among the groups before and during follow up visits.

Table 30:- Comparison between the difference in the number of days of absence from school per week due to asthma before follow up and at each follow up visit in all subgroups

\begin{tabular}{|l|l|l|l|}
\hline & $\begin{array}{l}\mathbf{6}-5 \\
\text { years }\end{array}$ & $\begin{array}{l}>5 \\
8 \mathrm{years}\end{array}$ & $\begin{array}{l}\mathbf{> 8} \\
12 \mathrm{year} \\
\mathrm{s}\end{array}$ \\
\hline Paired t-test & \multicolumn{2}{|c|}{} \\
\hline $\begin{array}{l}\text { Difference in number of days of absence from school per week due to asthma } \\
\text { before follow up and at } 2 \text { weeks follow up visit. }\end{array}$ & 0.815 & 0.000 & 0.000 \\
\hline $\begin{array}{l}\text { Difference in number of days of absence from school per week due to asthma } \\
\text { before follow up and at } 4 \text { weeks follow up visit }\end{array}$ & 0.000 & 0.000 & 0.000 \\
\hline Difference in number of days of absence from school per week due to asthma & 0.000 & 0.000 & 0.000 \\
\hline
\end{tabular}


before follow up and at 8 weeks follow up visit Difference in number of days of absence from school per week due to asthma before follow up and at 12 weeks follow up visit

\begin{tabular}{|l|l|l|} 
& & \\
0.000 & 0.000 & 0.000
\end{tabular}

By using paired t-test this table shows comparison number of days of absence from school per week due to asthma before follow up and at each follow up visit in all subgroups (B1, B2, B3) and it was noticed that no statistically significance in comparison in all subgroups

Table 31:- comparison between the subgroups of the intervention group as regard number of times of E.D. visits per week due to asthma before and during the follow up visit.

\begin{tabular}{|c|c|c|c|c|c|c|c|c|c|c|}
\hline \multirow[b]{3}{*}{ Intervention } & \multicolumn{10}{|l|}{ Age } \\
\hline & \multicolumn{2}{|c|}{$6 m-5 y$} & \multicolumn{3}{|c|}{$>5-8$} & \multicolumn{3}{|c|}{$>8-12$} & \multicolumn{2}{|c|}{ ANOVA } \\
\hline & $\begin{array}{l}\text { Me } \\
\text { an }\end{array}$ & & & \pm & & & \pm & $\begin{array}{l}\text { S } \\
\mathbf{D}\end{array}$ & f & $\begin{array}{l}\text { P- } \\
\text { valu } \\
\text { e }\end{array}$ \\
\hline $\begin{array}{l}\text { Number of times of E.D. visits per week due to } \\
\text { asthma before follow up visits }\end{array}$ & $\begin{array}{l}1.8 \\
5\end{array}$ & $\begin{array}{l}0 . \\
67\end{array}$ & $\begin{array}{l}2.1 \\
1\end{array}$ & \pm & $\begin{array}{l}0 . \\
66\end{array}$ & $\begin{array}{l}2.0 \\
5\end{array}$ & \pm & $\begin{array}{l}0 . \\
74\end{array}$ & $\begin{array}{l}0.7 \\
39\end{array}$ & $\begin{array}{l}0.48 \\
2\end{array}$ \\
\hline $\begin{array}{l}\text { Number of times of E.D. visits per week due to } \\
\text { asthma at } 2 \text { weeks follow up visit. }\end{array}$ & $\begin{array}{l}0.7 \\
5\end{array}$ & $\begin{array}{l}0 . \\
44\end{array}$ & $\begin{array}{l}0.6 \\
3\end{array}$ & \pm & $\begin{array}{l}0 . \\
60\end{array}$ & $\begin{array}{l}0.6 \\
2\end{array}$ & \pm & 0. & $\begin{array}{l}0.3 \\
96\end{array}$ & $\begin{array}{l}0.67 \\
5\end{array}$ \\
\hline $\begin{array}{l}\text { Number of times of E.D. visits per week due to } \\
\text { asthma at } 4 \text { weeks follow up visit }\end{array}$ & $\begin{array}{l}0.7 \\
0\end{array}$ & $\begin{array}{l}0 . \\
57\end{array}$ & $\begin{array}{l}0.4 \\
7\end{array}$ & \pm & $\begin{array}{l}0 . \\
51\end{array}$ & $\begin{array}{l}0.4 \\
3\end{array}$ & \pm & $\begin{array}{l}0 . \\
51\end{array}$ & $\begin{array}{l}1.5 \\
13\end{array}$ & $\begin{array}{l}0.22 \\
9\end{array}$ \\
\hline $\begin{array}{l}\text { Number of times of E.D. visits per week due to } \\
\text { asthma at } 8 \text { weeks follow up visit }\end{array}$ & $\begin{array}{l}0.6 \\
5\end{array}$ & $\begin{array}{l}0 . \\
67\end{array}$ & $\begin{array}{l}0.5 \\
3\end{array}$ & \pm & $\begin{array}{l}0 . \\
51\end{array}$ & $\begin{array}{l}0.4 \\
8\end{array}$ & \pm & $\begin{array}{l}0 . \\
51\end{array}$ & $\begin{array}{l}0.5 \\
00\end{array}$ & $\begin{array}{l}0.60 \\
9\end{array}$ \\
\hline $\begin{array}{l}\text { Number of times of E.D. visits per week due to } \\
\text { asthma at } 12 \text { weeks follow up visit. }\end{array}$ & $\begin{array}{l}0.3 \\
5\end{array}$ & $\begin{array}{l}0 . \\
49\end{array}$ & $\begin{array}{l}0.3 \\
2\end{array}$ & \pm & $\begin{array}{l}0 . \\
48\end{array}$ & $\begin{array}{l}0.5 \\
7\end{array}$ & \pm & $\begin{array}{l}0 . \\
51\end{array}$ & $\begin{array}{l}1.6 \\
22\end{array}$ & $\begin{array}{l}0.20 \\
7\end{array}$ \\
\hline
\end{tabular}

This table shows that no statistically significant in comparison between subgroups (B1, B2, B3).

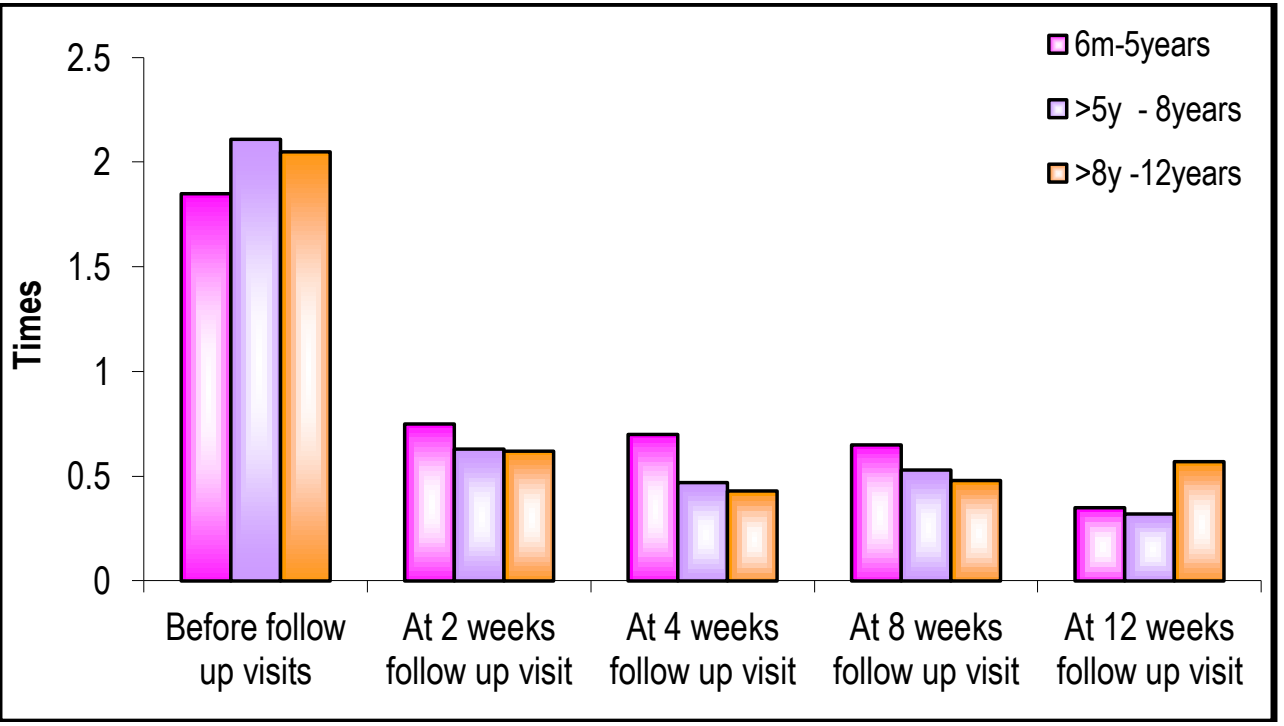

Figure 21:- Comparison between the subgroups of the intervention group as regard number of times of

E.D. visits per week due to asthma among the groups before and during and during the follow up visits.

Table 32:- Comparison between the difference in number of times of e.d. visits per week due to asthma before follow up and at each follow up visit in all subgroups.

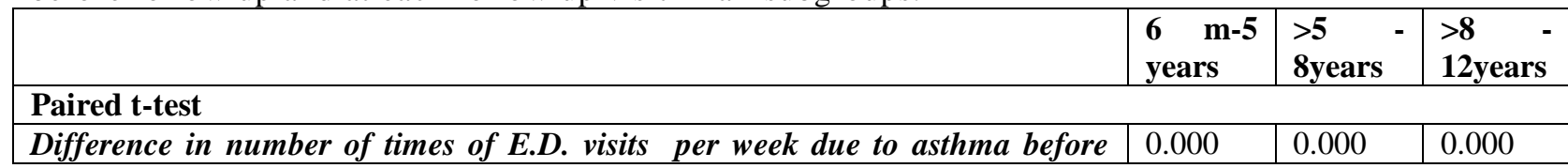


follow up and at 2 weeks follow up visit Difference in number of times of E.D. visits per week due to asthma before follow up and at 4 weeks follow up visit Difference in number of times of E.D. visits per week due to asthma before follow up and at 8 weeks follow up visit Difference in number of times of E.D. visits per week due to asthma before follow up and at 2 weeks follow up visit

\begin{tabular}{|l|l|l|} 
& & \\
0.000 & 0.000 & 0.000 \\
\hline 0.000 & 0.000 & 0.000 \\
\hline 0.000 & 0.000 & 0.000 \\
\hline
\end{tabular}

By using paired t-test this table shows that no statistically significance in comparison in all subgroups

Table 33:- Comparison between the subgroups of the intervention group as regard times of use of rescue therapy per week among the groups before and during the follow up visits.

\begin{tabular}{|c|c|c|c|c|c|c|c|c|c|c|c|}
\hline \multirow{3}{*}{ Intervention } & \multicolumn{11}{|c|}{ Age } \\
\hline & \multicolumn{3}{|c|}{$6 \mathrm{~m}-5$ years } & \multicolumn{3}{|c|}{$>5$ - 8years } & \multicolumn{3}{|c|}{$>8$-12years } & \multicolumn{2}{|c|}{ ANOVA } \\
\hline & & & SD & $\begin{array}{l}\text { Me } \\
\text { an }\end{array}$ & & SD & $\begin{array}{l}\text { Me } \\
\text { an }\end{array}$ & \pm & SD & f & $\begin{array}{l}\text { P- } \\
\text { value }\end{array}$ \\
\hline $\begin{array}{l}\text { Number of times of use of rescue therapy before } \\
\text { follow up visits. }\end{array}$ & 6.15 & + & $\begin{array}{l}1.1 \\
4\end{array}$ & 6.05 & + & $\begin{array}{l}1.2 \\
7\end{array}$ & 6.38 & \pm & $\begin{array}{l}1.2 \\
8\end{array}$ & $\begin{array}{l}0.3 \\
79\end{array}$ & 0.686 \\
\hline $\begin{array}{l}\text { Number of times of use of rescue therapy at } 2 \\
\text { weeks follow up visit }\end{array}$ & 1.10 & + & $\begin{array}{l}0.7 \\
2\end{array}$ & 1.00 & \pm & $\begin{array}{l}0.7 \\
5\end{array}$ & 0.95 & \pm & $\begin{array}{l}0.8 \\
3\end{array}$ & $\begin{array}{l}0.1 \\
99\end{array}$ & 0.820 \\
\hline $\begin{array}{l}\text { Number of times of use of rescue therapy at } 4 \\
\text { weeks follow up visit }\end{array}$ & 0.90 & \pm & $\begin{array}{l}0.4 \\
5\end{array}$ & 0.79 & \pm & $\begin{array}{l}0.7 \\
1\end{array}$ & 1.05 & \pm & $\begin{array}{l}0.8 \\
0\end{array}$ & $\begin{array}{l}0.7 \\
40\end{array}$ & 0.481 \\
\hline $\begin{array}{l}\text { Number of times of use of rescue therapy at } 8 \\
\text { weeks follow up visit }\end{array}$ & 0.95 & \pm & $\begin{array}{l}0.7 \\
6\end{array}$ & 1.11 & \pm & $\begin{array}{l}0.7 \\
4\end{array}$ & 0.76 & \pm & $\begin{array}{l}0.5 \\
4\end{array}$ & $\begin{array}{l}1.2 \\
71\end{array}$ & 0.288 \\
\hline $\begin{array}{l}\text { Number of times of use of rescue therapy at } 12 \\
\text { weeks follow up visit }\end{array}$ & 0.80 & \pm & $\begin{array}{l}0.7 \\
0\end{array}$ & 0.47 & \pm & $\begin{array}{l}0.5 \\
1\end{array}$ & 0.48 & \pm & $\begin{array}{l}0.6 \\
8\end{array}$ & $\begin{array}{l}1.7 \\
32\end{array}$ & 0.186 \\
\hline
\end{tabular}

This table shows that no statistically significant in comparison between subgroups (B1, B2, B3).

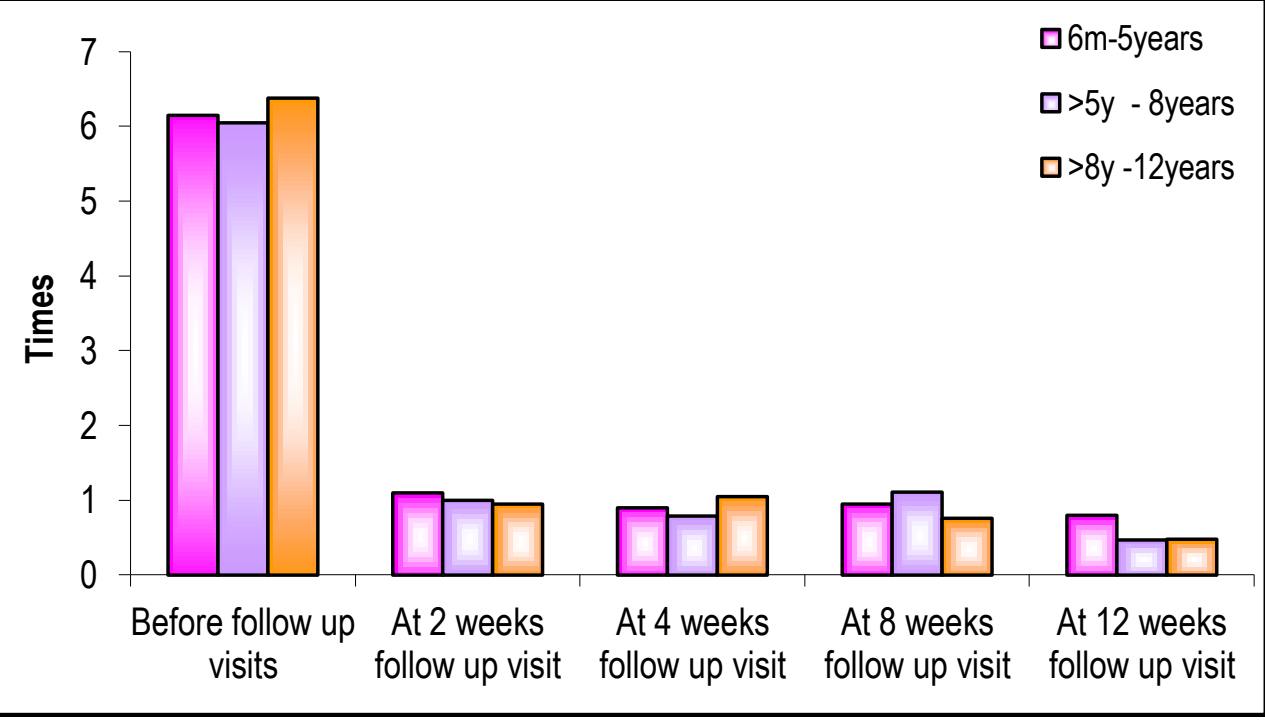

Figure 22:- Comparison between the subgroups of the intervention group as regard times of use of rescue therapy per week among the groups before and during the follow up visits.

Table 34:- Comparison between the difference in the number times of use of rescue therapy per week before follow up and at each follow up visit in all subgroups.

\begin{tabular}{|l|l|l|l|l|}
\hline \multicolumn{1}{|l|}{} & $\begin{array}{l}6 \\
\text { years }\end{array}$ & $\begin{array}{l}>5 \\
8 \text { years }\end{array}$ & $\begin{array}{l}>8 \\
12 y e a r s\end{array}$ \\
\hline Paired t-test & \multicolumn{1}{|l|}{$\mid$} \\
\hline Difference in number of times of use of rescue therapy per week before follow & 0.000 & 0.000 & 0.000 \\
\hline
\end{tabular}




\begin{tabular}{|c|c|c|c|}
\hline 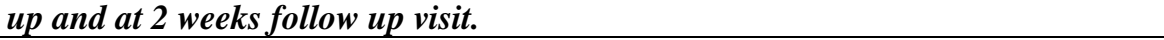 & & & \\
\hline $\begin{array}{l}\text { Difference in number of times of use of rescue therapy per week before follow } \\
\text { up and at } 4 \text { weeks follow up visit }\end{array}$ & 0.000 & 0.000 & 0.000 \\
\hline $\begin{array}{l}\text { Difference in number of times of use of rescue therapy per week before follow } \\
\text { up and at } 8 \text { weeks follow up visit }\end{array}$ & 0.000 & 0.000 & 0.000 \\
\hline $\begin{array}{l}\text { Difference in number of times of use of rescue therapy per week before follow } \\
\text { up and at } 12 \text { weeks follow up visit }\end{array}$ & 0.000 & 0.000 & 0.000 \\
\hline
\end{tabular}

By using paired t-test this table that no statistically significance in comparison in all subgroups

Table 35:- Comparison between the subgroups of the intervention group as regard numbers of nights disturbance per week due to asthma among the groups before and during the follow up.

\begin{tabular}{|c|c|c|c|c|c|c|c|c|c|c|c|}
\hline \multirow[b]{3}{*}{ Intervention } & \multicolumn{11}{|c|}{ Age } \\
\hline & \multicolumn{3}{|c|}{$6 \mathrm{~m}-5$ yeras } & \multicolumn{3}{|c|}{$>5$ - 8years } & \multicolumn{3}{|c|}{$>8$-12years } & \multicolumn{2}{|c|}{ ANOVA } \\
\hline & $\begin{array}{l}\text { M } \\
\text { an }\end{array}$ & \pm & $\begin{array}{l}\mathbf{S} \\
\mathbf{D}\end{array}$ & & \pm & $\begin{array}{l}\text { S } \\
\mathbf{D}\end{array}$ & $\begin{array}{l}\text { Me } \\
\text { an }\end{array}$ & \pm & & $\mathbf{f}$ & $\begin{array}{l}\text { P- } \\
\text { valu } \\
\text { e }\end{array}$ \\
\hline $\begin{array}{l}\text { Number of night disturbance per week due to } \\
\text { asthma before follow up visits }\end{array}$ & $\begin{array}{l}2.2 \\
0\end{array}$ & \pm & $\begin{array}{l}0 . \\
70\end{array}$ & $\begin{array}{l}2.1 \\
1\end{array}$ & \pm & $\begin{array}{l}0 . \\
81 \\
\end{array}$ & $\begin{array}{l}2.1 \\
0\end{array}$ & \pm & & $\begin{array}{l}0.11 \\
7\end{array}$ & $\begin{array}{l}0.89 \\
0\end{array}$ \\
\hline $\begin{array}{l}\text { Number of night disturbance per week due to } \\
\text { asthma at } 2 \text { weeks follow up visits }\end{array}$ & $\begin{array}{l}1.6 \\
0\end{array}$ & \pm & $\begin{array}{l}0 . \\
60\end{array}$ & $\begin{array}{l}0.4 \\
2\end{array}$ & \pm & $\begin{array}{l}0 . \\
51\end{array}$ & $\begin{array}{l}0.5 \\
7\end{array}$ & \pm & $\begin{array}{l}0 . \\
51\end{array}$ & $\begin{array}{l}28.1 \\
29\end{array}$ & $\begin{array}{l}0.00 \\
0\end{array}$ \\
\hline $\begin{array}{l}\text { Number of night disturbance per week due to } \\
\text { asthma at } 4 \text { weeks follow up visits }\end{array}$ & $\begin{array}{l}0.9 \\
5\end{array}$ & \pm & $\begin{array}{l}0 . \\
60\end{array}$ & $\begin{array}{l}0.3 \\
2\end{array}$ & \pm & $\begin{array}{l}0 . \\
48\end{array}$ & $\begin{array}{l}0.3 \\
3\end{array}$ & \pm & $\begin{array}{l}0 . \\
48\end{array}$ & $\begin{array}{l}9.44 \\
7\end{array}$ & $\begin{array}{l}0.00 \\
0\end{array}$ \\
\hline $\begin{array}{l}\text { Number of night disturbance per week due to } \\
\text { asthma at 8weeks follow up visits }\end{array}$ & $\begin{array}{l}0.5 \\
0\end{array}$ & \pm & $\begin{array}{l}0 . \\
61 \\
\end{array}$ & $\begin{array}{l}0.4 \\
7\end{array}$ & \pm & $\begin{array}{l}0 . \\
51 \\
\end{array}$ & $\begin{array}{l}0.2 \\
4\end{array}$ & & & $\begin{array}{l}1.56 \\
5 \\
\end{array}$ & $\begin{array}{l}0.21 \\
8 \\
\end{array}$ \\
\hline $\begin{array}{l}\text { Number of night disturbance per week due to } \\
\text { asthma at } 12 \text { weeks follow up visits }\end{array}$ & $\begin{array}{l}0.2 \\
0\end{array}$ & & $\begin{array}{l}0 . \\
52\end{array}$ & $\begin{array}{l}0.2 \\
1\end{array}$ & \pm & $\begin{array}{l}0 . \\
42\end{array}$ & & & $\begin{array}{l}0 . \\
48\end{array}$ & $\begin{array}{l}0.49 \\
3\end{array}$ & $\begin{array}{l}0.61 \\
3\end{array}$ \\
\hline
\end{tabular}

This table shows no statistically significant in comparison between subgroups (B1, B2, B3).

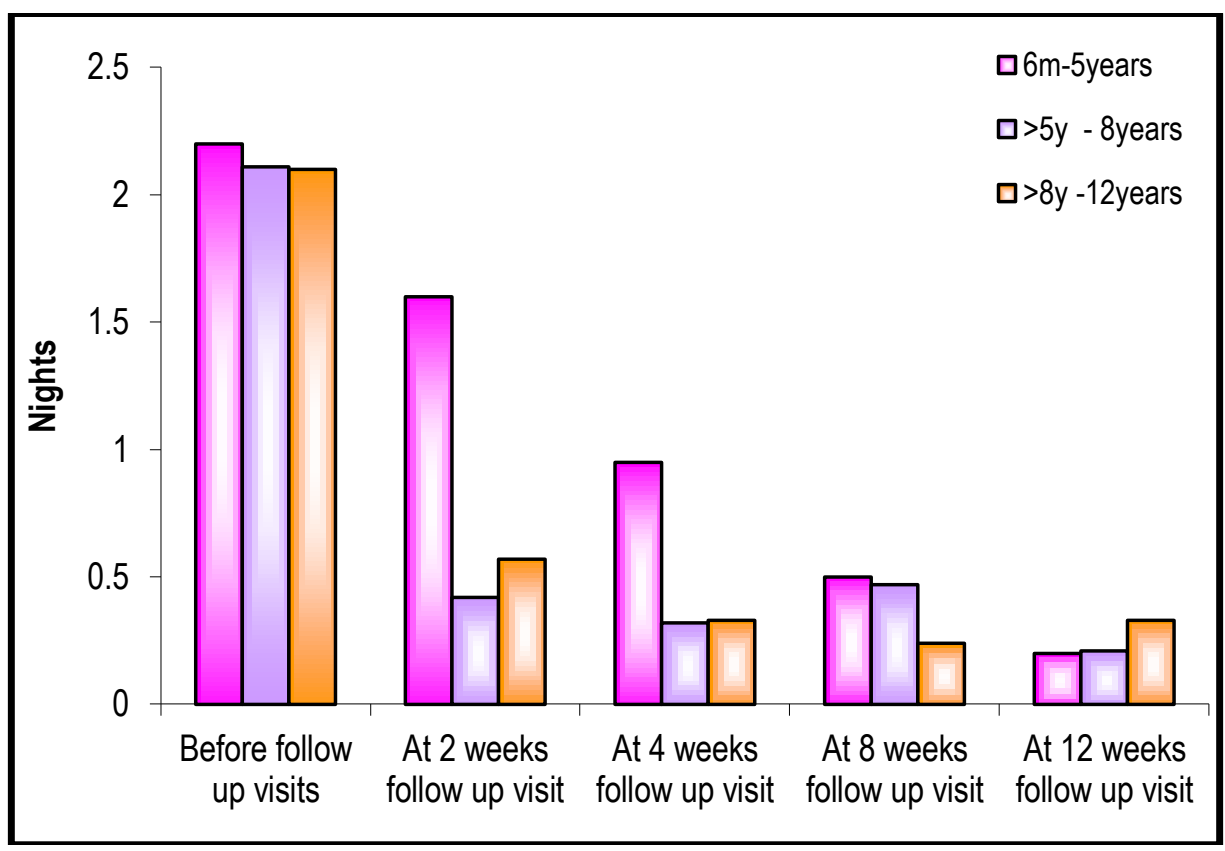

Figure 23:- comparison between the subgroups of the intervention as regard number of night disturbance per week due to asthma among the groups before and during the follow up visits. 
Table 36:- Comparison between the difference in the number of nights disturbance per week due to asthma before follow up and at each follow up visit in all subgroups.

\begin{tabular}{|l|l|l|l|l|}
\hline $\begin{array}{l}\mathbf{7} \\
\text { Paired t-test }\end{array}$ & $\begin{array}{l}\mathbf{m}-5 \\
\text { years }\end{array}$ & $\begin{array}{l}>5 \\
8 \mathrm{y} e a r s\end{array}$ & $\begin{array}{l}>8 \\
12 \mathrm{y} e a r s\end{array}$ \\
\hline $\begin{array}{l}\text { Difference in number of night disturbance per week due to asthma before } \\
\text { follow up and at } 2 \text { weeks follow up visit }\end{array}$ & 0.001 & 0.000 & 0.000 \\
\hline $\begin{array}{l}\text { Difference in number of night disturbance per week due to asthma before } \\
\text { follow up and at } 4 \text { weeks follow up visit }\end{array}$ & 0.000 & 0.000 & 0.000 \\
\hline $\begin{array}{l}\text { Difference in number of night disturbance per week due to asthma before } \\
\text { follow up and at 8weeks follow up visit }\end{array}$ & 0.000 & 0.000 & 0.000 \\
\hline $\begin{array}{l}\text { Difference in number of night disturbance per week due to asthma before } \\
\text { follow up and at } 12 \text { weeks follow up visit }\end{array}$ & 0.000 & 0.000 & 0.000 \\
\hline
\end{tabular}

By using paired t-test this table shows comparison number of nights disturbance per week due to asthma before follow up and at each follow up visit in all subgroups (B1, B2, B3) and it was noticed that no statistically significance in comparison in all subgroups.

Table 37:- Comparison between the subgroups of the intervention group as regard number of days of admission to hospital per week due to asthma among the groups before and during the follow up visits.

\begin{tabular}{|c|c|c|c|c|c|c|c|c|c|c|c|c|}
\hline \multirow[b]{3}{*}{ Intervention } & \multicolumn{12}{|l|}{ Age } \\
\hline & \multicolumn{3}{|c|}{$6 \mathrm{~m}-5$ years } & \multicolumn{3}{|c|}{$>5$ - 8years } & \multicolumn{3}{|c|}{$>8$-12years } & \multicolumn{3}{|c|}{ ANOVA } \\
\hline & $\begin{array}{l}\text { Me } \\
\text { an }\end{array}$ & & & & & & & & & f & & $\begin{array}{l}\text { P- } \\
\text { valu } \\
\text { e }\end{array}$ \\
\hline $\begin{array}{l}\text { Number of times of admission to hospital per week due } \\
\text { to asthma before follow up visits. }\end{array}$ & $\begin{array}{l}0.4 \\
5\end{array}$ & & & $\begin{array}{l}0.5 \\
3\end{array}$ & & & & & & & & $\begin{array}{l}0.56 \\
7\end{array}$ \\
\hline $\begin{array}{l}\text { Number of times of admission to hospital per week due } \\
\text { to asthma at } 2 \text { weeks follow up visit. }\end{array}$ & & & & $\begin{array}{l}0.2 \\
6\end{array}$ & & & $\begin{array}{l}0.2 \\
9\end{array}$ & & & & & $\begin{array}{l}0.62 \\
4\end{array}$ \\
\hline $\begin{array}{l}\text { Number of times of admission to hospital per week due } \\
\text { to asthma at } 4 \text { weeks follow up visit }\end{array}$ & & & & $\begin{array}{l}0.2 \\
1\end{array}$ & & & $\begin{array}{l}0 . \\
0\end{array}$ & & $\begin{array}{l}0 \\
3 \\
\end{array}$ & & & $\begin{array}{l}0.14 \\
6\end{array}$ \\
\hline $\begin{array}{l}\text { Number of times of admission to hospital per week due } \\
\text { to asthma at } 8 \text { weeks follow up visit }\end{array}$ & $\begin{array}{l}0.4 \\
5\end{array}$ & & & $\begin{array}{ll}0.1 \\
1\end{array}$ & & $\begin{array}{l}0 . \\
32 \\
\end{array}$ & $\begin{array}{l}0 . \\
4\end{array}$ & & 0. & & & $\begin{array}{l}0.01 \\
7\end{array}$ \\
\hline $\begin{array}{l}\text { Number of times of admission to hospital per week due } \\
\text { to asthma at } 12 \text { weeks follow up visit }\end{array}$ & & & & & & & $\begin{array}{ll}0.1 \\
5\end{array}$ & & & & & $\begin{array}{ll}0.09 \\
7\end{array}$ \\
\hline
\end{tabular}

This table shows that no statistically significant in comparison between subgroups (B1, B2, B3).

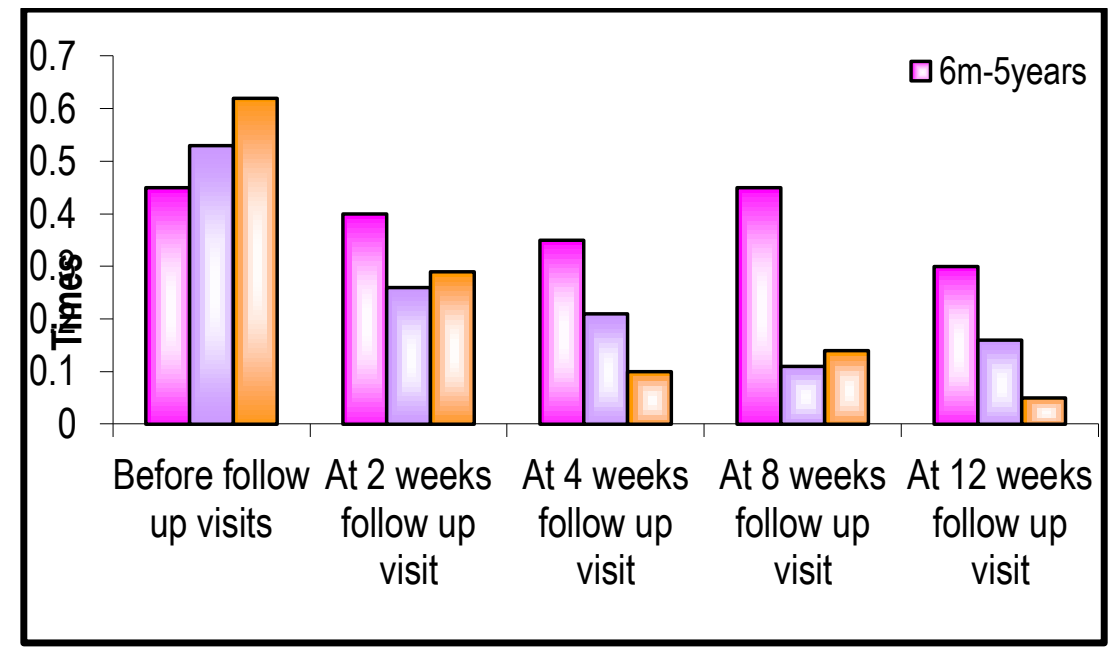

Figure 24:- comparison between subgroups of the interventional group as regard number of days of admission to hospital per week due to asthma among the groups before and during the follow up visit. 
Table 38:- Comparison between the difference in the number of days of admission to hospital per week due to asthma before follow up and at each follow up visit in all subgroups.

\begin{tabular}{|c|c|c|c|}
\hline & $\begin{array}{l}6 \mathrm{~m}-5 \\
\text { years }\end{array}$ & $\begin{array}{l}>5 \\
\text { 8years }\end{array}$ & $\begin{array}{lr}>8 \\
12 \text { years }\end{array}$ \\
\hline \multicolumn{4}{|l|}{ Paired t-test } \\
\hline $\begin{array}{l}\text { Difference in times of admission to hospital per week due to asthma before } \\
\text { follow up and at } 2 \text { weeks follow up visit. }\end{array}$ & 0.772 & 0.135 & 0.031 \\
\hline $\begin{array}{l}\text { Difference in times of admission to hospital per week due to asthma before } \\
\text { follow up and at } 4 \text { weeks follow up visit }\end{array}$ & 0.494 & 0.010 & 0.001 \\
\hline $\begin{array}{l}\text { Difference in times of admission to hospital per week due to asthma before } \\
\text { follow up and at } 8 \text { weeks follow up visit }\end{array}$ & 1.000 & 0.007 & 0.002 \\
\hline $\begin{array}{l}\text { Difference in times of admission to hospital per week due to asthma before } \\
\text { follow up and at } 12 \text { weeks follow up visit }\end{array}$ & 0.267 & 0.031 & 0.000 \\
\hline
\end{tabular}

By using paired t-test this table shows comparison number of days of admission to hospital per week due to asthma before follow up and at each follow up visit in all subgroups (B1, B2, B3) and it was noticed that no statistically significance in comparison in all subgroups .

Table 39:- Comparison between subgroups of the intervention group as regard eosinophilic count before and after follow up visits.

\begin{tabular}{|c|c|c|c|c|c|c|c|c|c|c|c|}
\hline \multirow{3}{*}{ Intervention } & \multicolumn{11}{|l|}{ Age } \\
\hline & \multicolumn{3}{|c|}{$6 \mathrm{~m}-5$ years } & \multicolumn{3}{|c|}{$>5$ - 8years } & \multicolumn{3}{|c|}{$>8$-12years } & \multicolumn{2}{|c|}{ ANOVA } \\
\hline & $\begin{array}{l}\text { Mea } \\
\text { n }\end{array}$ & \pm & SD & $\begin{array}{l}\text { Mea } \\
n\end{array}$ & \pm & SD & $\begin{array}{l}\text { Mea } \\
\text { n }\end{array}$ & \pm & SD & f & $\begin{array}{l}\text { P- } \\
\text { value }\end{array}$ \\
\hline $\begin{array}{l}\text { Eosinophilic count before follow up } \\
\text { visits. }\end{array}$ & 1.75 & \pm & $\begin{array}{l}1.0 \\
2\end{array}$ & 4.16 & \pm & $\begin{array}{l}1.7 \\
1\end{array}$ & 2.00 & \pm & $\begin{array}{l}1.0 \\
5\end{array}$ & $\begin{array}{l}20.59 \\
4\end{array}$ & 0.000 \\
\hline $\begin{array}{l}\text { Eosinophilic count after follow up } \\
\text { visits. }\end{array}$ & 1.35 & \pm & $\begin{array}{l}1.0 \\
4\end{array}$ & 3.05 & \pm & $\begin{array}{l}1.3 \\
5\end{array}$ & 1.57 & \pm & $\begin{array}{l}1.0 \\
8\end{array}$ & $\begin{array}{l}12.38 \\
1\end{array}$ & 0.000 \\
\hline
\end{tabular}

This table shows that the mean value of the esinophilic count was the highest in the age groups from 5 to 8 years

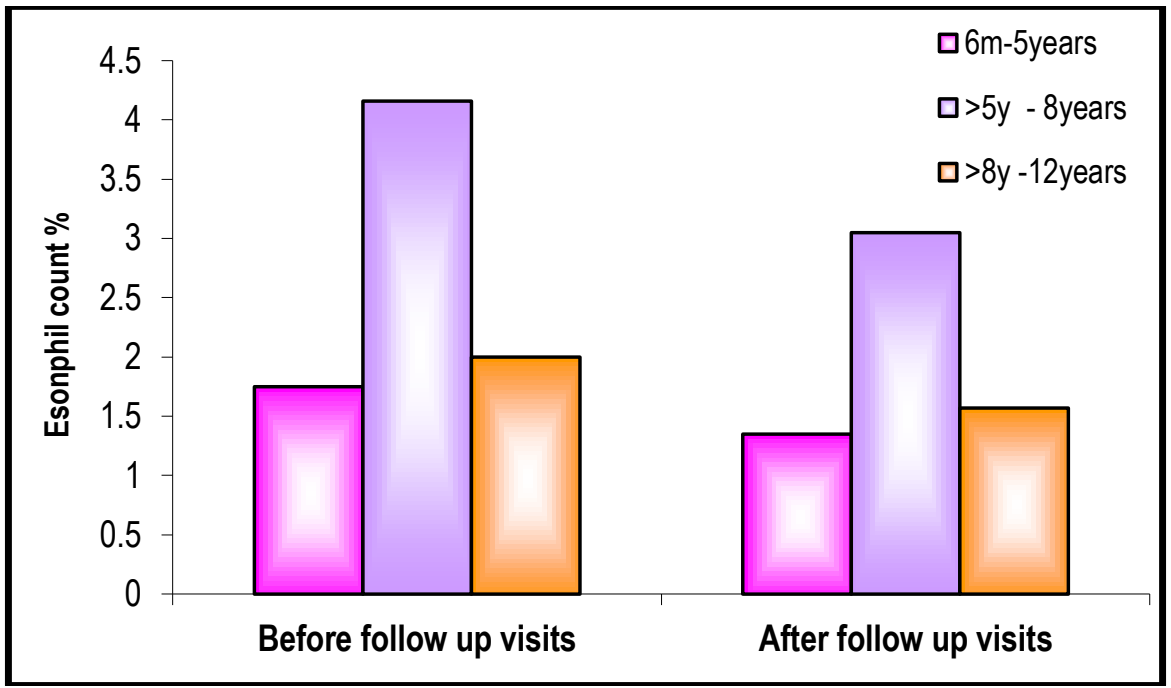

Figure 25:- Comparison between subgroups of the intervention group as regard eosinophilic count before and after sessions

Table 40:- Comparison between subgroups of the intervention group as regard eosinophilic count before and after sessions

\begin{tabular}{|l|l|l|l|}
\hline Paired t-test & $\mathbf{6}$ m-5 years & $>\mathbf{5}$ - 8years & $>\mathbf{8}$-12years \\
\hline $\begin{array}{l}\text { Difference between eosinophilic count before and after follow up } \\
\text { visits. }\end{array}$ & 0.138 & $0.007^{*}$ & 0.123 \\
\hline
\end{tabular}


By using paired t-test this table show no statistically significance in comparison between subgroups as regard eosinophilic count before and after follow up visits.

\section{Discussion:-}

Asthma is a common cause of emergency room visits and hospital admissions. the burden of asthma is higher than generally recognized, particularly in children. For example, in Egypt up to one in four children with asthma is unable to attend school regularly because of poor asthma control (7).

Asthma education that is directed at self-management can reduce morbidity, improve lung function, feelings of self control, reduce absenteeism from school, number of days with restricted activity, number of visits to the emergency department, and possibly the number of sleep disturbed nights $(\mathbf{8})$.

The present study included 61 male child and 29 female child. Generally, asthma is more common in boys at school age (9). The reasons for this sex related difference are not clear. However, lung size is smaller in males than in females at Birth. Age and sex had no relation, in the present study, to asthma symptoms, restricted child's physical activity or the rate of asthma attacks .

In the present study there was statistically significant reductions in the mean number of days with restricted activities from $(1.97 \pm 0.80)$ in the first visit to $(0.28 \pm 0.15)$ in the fourth follow up visit with $P$ value $<0.001$. The reduction of days with asthma symptoms was progressively increasing in the follow up visits.

These results were in agree with the results obtained by Clark, et al 2004 which showed a significant decline in daytime symptoms by the time of the second follow-up. Treated children experienced fewer days with symptoms when compared to control children ( $\mathrm{P}$ value $<0.0001)$.

The results also matched with the study done by $\boldsymbol{B u t z}$ (10) to determine the effectiveness of an asthma educational intervention in improving asthma knowledge, self-efficacy, and quality of life in rural families. Their results revealed that asthma education of children 6 to 12 years of age was associated with statistically significant reductions in the mean number of days with asthma symptoms.

Number of nights disturbed by asthma symptoms was, also statistically significant less in the fourth follow up visit $(0.25 \pm 0.12)$, compared to the first visit $(0.87 \pm 0.45)$, with $\mathrm{P}$ value $<0.001$. These results were in agree with the results obtained by Toelle et al., (11) who assessed whether school-based asthma education affected the number of nights on which children experienced nocturnal symptoms and found that asthma education led to a statistically significant reduction in nights disturbed by asthma symptoms relative to children who received usual care. The results also agree with that obtained by Deaves, (12), who reported significant improvement in night symptoms during assessment of the value of health education in the prevention of childhood asthma.

Regarding school absences in the present study, it was found that there was a decrease in the number of schoolabsence days from $(0.98 \pm 0.41)$ in the first follow up visit to $(0.25 \pm 0.10)$ at the fourth follow up visit. Levy et al. (13); reported similar findings among children who received the asthma education intervention compared to children who received usual care.

The present study showed a decrease in $\boldsymbol{E D}$. visits for asthma from $(0.67 \pm 0.51)$ in the first follow up visit to $(0.42 \pm 0.50)$ at the fourth follow up visit. These results also agree with the results obtained by Tinkelman and Schwartz,(14) who showed that a comprehensive, school-based asthma management program can successfully reduce unscheduled doctor visits by two thirds. This can be attributed to educating parents and their children about self monitoring of exacerbation by symptoms and managing these exacerbations by modifying the dosages of drugs, especially controlled medication.

Osman et al.,(15) showed that One month after discharge self management program (SMP) patients were more likely than standard care (SC) patients to report no daytime wheeze (OR 2.6, 95\% CI 1.5 to 5.3), no night disturbance (OR 2.0, 95\% CI 1.2 to 3.5), and no activity limitation (OR 1.5, 95\% CI 0.9 to 2.7). Over 12 months $17 \%$ of SMP patients were re-admitted compared with $27 \%$ of SC patients (OR $0.5,95 \%$ CI 0.3 to 1.0). Among first admission patients, OR readmission (SMP v SC) was 0.2 (95\% CI 0.1 to 0.7 ), p<0.01. For patients with a previous 
admission, OR readmission was 0.8 (95\% CI 0.4 to 1.6), $\mathrm{p}=0.6$. SMP patients were more likely than SC patients to be prescribed inhaled steroids at discharge $(99 \% \mathrm{v} 92 \%, \mathrm{p}=0.03)$, oral steroids $(98 \% \mathrm{v} 90 \%, \mathrm{p}=0.06)$, and to have hospital follow up $(98 \% \mathrm{v} 84 \%, \mathrm{p}<0.01)$ but adjustment for these differences did not diminish the effect of the selfmanagement program.

In the current study, it was found that there was decrease in the use of use of rescue therapy from (1.02 \pm 0.75$)$ in the first follow up visit to $(0.85 \pm 0.65)$ at the fourth follow up visit. . Similar results were reported in the study done by Levy et al. (2000) which showed that the educated patients in hospital-based nurse specialist delivered selfmanagement education during three sessions had significantly decreased in the use of SABA for quick relief of symptoms for asthma after 6 months Compared to patients receiving usual care.

Not only asthma symptoms improved but also patient and family satisfaction with asthma self-management program was obvious. Same conclusion was reported by Maridee Jones, (16).

In the present study age and sex did not show to influence the response to the education session.

In the present study the educational intervention was conducted to the children and their family through individual meeting with patients and their families, supported with an asthma action plan and reassessment through four follow up visits.

In the current study only 90 children out of 177 (50\%) asthmatic children continued follow up for next 5 visits. Several factors might contribute to non adherence of $50 \%$ of patients who received the first education session. Costs of traveling may be one factor but undiscussed fears or concerns and unclear message on part of the instructor may be another factor.

Increasing awareness of nature of the diseases allowed patients and families to adopt a self management plan of the diseases at home and decreased the rush in seeking medical advice for each episode of worsening symptoms.

Asthma symptoms during night and days became significantly less, however after the $3^{\text {rd }}$ visit; representing the time when the educational sessions resulted in virtual control of the diseases. The number of puffs per day of quick-relief medication became, also significantly less after the $\quad 3^{\text {rd }}$ visit significant.

The number of asthma attacks requiring visiting the doctor or emergency room, however became significantly less by the $4^{\text {th }}$ visit. Although this result would suggest incomplete control of asthma, it may, on the other hand, represent appropriate judgment of patients and their families as when to seek medical advice.

The key factor in the present study was the interactive educational sessions by a physician to provide and reinforce the educational endeavor which increase adherence to the asthma guidelines, improve quality of care and patient outcomes.

It was noted in the present study that education level and age doesn't affect the outcome any of parameter that used in the research that used to assess the outcome of the AEP on childhood asthma.

So we can consider that AEP is a sufficient curriculum to be used in small group interactive education to different age groups and education level.

Also, eosinophilic count decline significantly after control of the six parameter mentioned previously from $(2.60 \pm 1.66)$ before follow up visits to $(1.97 \pm 1.37)$ after follow up visits in the intervention group.

Collectively, education session during chest clinic visit could result in a better asthma control. It is not surprising that children who knew more about asthma and who had better self-management skills, avoidance of environment triggers, better inhalation technique, and closer adherence to therapeutic regimens could have a reduction in asthma symptoms 


\begin{abstract}
:-
Asthma is the most common chronic disease among children, with a significant increase in its prevalence, especially in recent decades.
\end{abstract}

This study was conducted at Al-Azhar university hospital allergy pulmonology follow up Clinic and included ninety children, 6 months -12 years old, and their families from Jun. to Nov. (2013).

The thesis was performed to study the impact of the asthma education sessions on the out come of asthma management in children.

The study revealed that asthma educational session have a positive impact on management of asthmatic children in the form of:

1. Reduction in the number of nights disturbed by asthma symptoms from $2.13 \pm 0.68$ in the first visit to $0.25 \pm 0.12$ in the fourth follow up visit

2. Decrease in the number of children restricted physical activity and school absences days due to asthma symptoms from $1.97 \pm 0.80$ in the first follow up visit to $0.28 \pm 0.15$ in the fourth follow up visit.

3. Decrease in the number of E.D. visits for asthma from $2.00 \pm 0.69$ in the first follow up visit to $0.42 \pm 0.50$ in the fourth follow up visit.

4. Decrease in mean of the use of quick-relief medication from Mean $6.20 \pm 1.22$ in the first follow up visit to 0.58 \pm 0.65 in the fourth follow up visit.

5. Decrease in days of absence from school from Mean $2.13 \pm 0.68$ in the first follow up visit to $0.25 \pm 0.10$ in the fourth follow up visit .

6. Decrease in numbers of admission to hospital from mean $0.73 \pm 30$ in the first follow up visit to $0.17 \pm 0.18$ in the fourth follow up visit.

7. Decrease in numbers of eosinophilic count from mean $2.60 \pm 1.66$ before education sessions to $1.97 \pm 1.37$ after education sessions.

In conclusion, the present study showed that an educational session provided by the treating physician during the first visit to chest asthma clinic could improve the outcome of asthma management plan in children with bronchial asthma.

\title{
References:-
}

1. Sullivan SD, Weiss KB. Health economics of asthma and rhinitis. II. Assessing the value of interventions. J Allergy Clin Immunol. 2001;107:203-10.

2. Gibson $\boldsymbol{P}$ and Powell H. 2004: Written action plans for asthma: an evidence-based review of the key components. Thorax; 59(2):94-9.

3. Yoon R, McKenzie DK, Bauman A, Miles DA. Controlled trial evaluation of an asthma education programme for adults. Thorax 1993; 48(11):1110-1116.

4. Abdulwadud O, Abramson M, Forbes A, James A, Walter EH (1999) Evaluation of a randomised controlled trial of adult asthma education in a hospital setting. Thorax 54:493-500

5. Marketos SG and Ballas $\boldsymbol{C N}$. 1982: Historical Perspectives: Bronchial Asthma in the MEdical Literature of Greek Antiquity. J.Asthma; 19:263-269

6. Rosner F. 1981: Moses Maimonides' treatise on asthma. Thorax; 36:245-251. PMID 7025335

7. GINA PED GUIDE 2012: Global Initiative for Asthma, Pocket guide for asthma management and prevention in children based on Global Strategy for Asthma Management and Prevention. Publications are available from http://www.ginasthma.com.

8. Bassili A, Zaki A, Zaher SR, El-Sawy IH, Ahmed MH, Omar M. Quality of care of children with chronic disease in Alexandria, Egypt: the models of asthma, type 1 diabetes, epilepsy, and rheumatic heart disease. Egyptian-Italian Collaborative Group on Pediatric Chronic Diseases. Pediatrics 2000;106 (1):E12.

9. Guevara JP, Wolf FM, Grum CM, Clark NM. 2003: Effects of educational interventions for self management of asthma in children and adolescents: systematic review and meta-analysis. BMJ; 326(7402): 1308-9

10. Elham M. Hossny, Zeinab E. Hasan, Mohamed F. Allam, Ezzat S. Mahmoud . Analysis of the filed data of a sample of Egyptian children with bronchial asthma .Egypt J Pediatr Allergy Immunol 2009;7(2):59-64. 59

11. Butz A, Pham L, Lewis L, Lewis C, Hill K, Walker J, Winkelstein M. 2005: Rural children with asthma: impact of a parent and child asthma education program. J Asthma; 42(10):813-21. 
12. Toelle BG, Ng KKW, Crisafulli D, Belousova EG, Almqvist C, Webb K, et al.; (1993): Eight-year outcomes of the Childhood Asthma Prevention Study. J Allergy Clin Immunol 2010; 126:388-9.

13. Deaves DM. An assessment of the value of health education in the prevention of childhood asthma. J Adv Nurs 1993;18(3):354-63.

14. Levy M., Fletcher M., Price D. Et al.(2006): International Primary Care Respiratory Group (IPCRG) Guidelines: diagnosis of respiratory diseases in primary care. Prim Care Respir J, 15(1):20-34.

15. Tinkelman D, Schwartz A. School-based asthma disease management. J Asthma. 2004;41 (4):455-462

16. Osman LM, Calder C, Godden DJ, Friend JA, McKenzie L, Legge JS, Douglas JG. 2002: A randomised trial of self-management planning for adult patients admitted to hospital with acute asthma. Thorax; 57(10):869-74.

17. Maridee. 